Check for updates

Cite this: RSC Adv., 2019, 9, 24963

Received 24th April 2019

Accepted 1st August 2019

DOI: 10.1039/c9ra03037a

rsc.li/rsc-advances

\title{
A comprehensive study of eriocitrin metabolism in vivo and in vitro based on an efficient UHPLC-Q- TOF-MS/MS strategy
}

\author{
Luya Li, (iD ${ }^{a}$ Xue Feng, ${ }^{a}$ Yuting Chen, ${ }^{a}$ Shenghao Li, ${ }^{b}$ Yupeng Sun ${ }^{a}$ \\ and Lantong Zhang ${ }^{\star a}$
}

\begin{abstract}
Eriocitrin, a main flavonoid in lemons, possesses strong antioxidant, lipid-lowering and anticancer activities and has long been used in food, beverages and wine. However, its metabolism in vivo and in vitro is still unclear. In this study, an efficient strategy was developed to detect and identify metabolites of eriocitrin by using ultra-high-performance liquid chromatography coupled with hybrid triple quadrupole time-offlight mass spectrometry (UHPLC-Q-TOF-MS) based on online data acquisition and multiple data processing techniques. A total of 32 metabolites in vivo and 27 metabolites in vitro were obtained based on the above method. Furthermore, the main metabolic pathways of eriocitrin included reduction, hydrogenation, $\mathrm{N}$-acetylation, ketone formation, oxidation, methylation, sulfate conjugation, glutamine conjugation, glycine conjugation, desaturation and demethylation to carboxylic acid. This study will lay a foundation for further studies on the metabolic mechanisms of eriocitrin.
\end{abstract}

\section{Introduction}

Eriocitrin (eriodictyol 7-O-beta-rutinoside), belonging to the dihydroflavonoid compound class, is widely found in citrus fruits (lemon, citrus, grapefruit), vegetables, processed products (drinks, wine) and so on. $\cdot^{1-3}$ Modern pharmacological studies show that eriocitrin has strong antioxidant, lipid-lowering and anticancer activities. ${ }^{4}$ It plays an important role in effectively preventing and improving oxidative stress, hyperlipidaemia, cardiovascular and cerebrovascular diseases as well as cancer. ${ }^{5-9}$

As found in the literature, three metabolites of eriocitrin were mentioned in plasma and renal-excreted urine, detected through HPLC and LC-MS analyses. ${ }^{10}$ However, until now, no structural information about the metabolites in bile, faeces, intestinal flora and liver microsomes of rats has been reported.

It is commonly known that drugs can have four pharmacological effects through biotransformation: (1) conversion into inactive substances; (2) transformation of the previously inactive drugs into active metabolites; (3) an alteration of the types of drug pharmacological action; (4) the production of toxic substances. ${ }^{11-13}$ Thus, it is crucial to study the metabolism of drugs in vivo to ensure safety of use. In addition, as the main metabolic organ of the human body, the liver is rich in enzymes,

${ }^{a}$ Department of Pharmaceutical Analysis, School of Pharmacy, Hebei Medical University, Shijiazhuang 050017, P. R. China. E-mail: zhanglantong@263.net; Fax: +86-311-86266419; Tel: +86-311-86266419

${ }^{b}$ Department of Pathobiology and Immunology, Hebei University of Chinese Medicine, Shijiazhuang 050000, P. R. China especially cytochrome P450 enzymes. ${ }^{14}$ In addition, the gastrointestinal tract is also an important place for drug metabolism, and its intestinal flora has a significant impact on drug absorption, metabolism and toxicology. ${ }^{15,16}$ Therefore, in this paper, mass spectrometry was used to investigate the metabolism of eriocitrin in rats, liver microsomes and intestinal flora in order to identify the metabolites and structural information of the products, which will lay a foundation for further studies on the toxicity and activity of metabolites and will provide greater possibilities for the development of new drugs.

With the development of technology, quadrupole time-offlight mass spectrometry has been widely used as a reliable analytical technique to detect metabolites due to its advantages of high resolution, high sensitivity, high-efficiency separation and accurate quality measurement. ${ }^{17,18}$ In this study, ultra-highperformance liquid chromatography coupled with hybrid triple quadrupole time-of-flight mass spectrometry (UHPLC-Q-TOFMS/MS) technology was used. The electrospray ionization (ESI) source was operated in negative ion mode, and full scan combined with multiple mass loss (MMDF) and dynamic background subtraction (DBS) was used to collect data online. MetabolitePilot 2.0.4 and PeakView 1.2 data loading software were adopted to obtain the precise mass number of metabolites, secondary mass spectrometry and decomposition rules of eriocitrin to infer the possible metabolites. Based on the above methods, 32 metabolites in vivo and 27 metabolites in vitro were finally observed. In addition, the metabolic pathways of eriocitrin were explored and summarized for the first time, which is an important part of drug discovery and development and can also provide a basis for further pharmacological research. 


\section{Materials and methods}

\subsection{Chemicals and materials}

Eriocitrin (13463-28-0, purity > 98.5\%) was purchased from Chengdu Desite Co., Ltd. (Chengdu, China). $\beta$-Nicotinamide adenine dinucleotide phosphate (NADPH) was purchased from Sigma Chemical (St. Louis, MO, USA). Alamethicin and uridine 5'-diphosphoglucuronic acid trisodium salt (UDPGA) were purchased from BD Biosciences (Woburn, MA, USA). Phosphate buffer saline (PBS) was purchased from Sangon Biotech (Shanghai) Co., Ltd. Acetonitrile, methanol and formic acid were all HPLC grade and were purchased from Fisher Scientific (Waltham, MA, USA). Dilute hydrochloric acid ( $\mathrm{HCl}$ ) was purchased from Shijiazhuang Reagent Factory. Purified water was purchased from Wahaha (Hangzhou Wahaha Group Co., Ltd.). L-Ascorbic acid, L-cysteine, eurythrol, tryptone and nutrient agar were purchased from Beijing AoBoXing Bio-tech (Beijing) Co., Ltd. Sodium carboxymethyl cellulose (CMC-Na), sodium carbonate $\left(\mathrm{Na}_{2} \mathrm{CO}_{3}\right)$, magnesium chloride $\left(\mathrm{MgCl}_{2}\right)$, potassium dihydrogen phosphate $\left(\mathrm{KH}_{2} \mathrm{PO}_{4}\right)$, dipotassium phosphate $\left(\mathrm{K}_{2} \mathrm{HPO}_{4}\right)$, calcium chloride $\left(\mathrm{CaCl}_{2}\right)$, ammonium sulfate $\left(\left(\mathrm{NH}_{4}\right)_{2} \mathrm{SO}_{4}\right)$, sodium chloride $(\mathrm{NaCl})$ and magnesium sulfate $\left(\mathrm{MgSO}_{4}\right)$ were obtained from Tianjin Guangfu Technology Development Co., Ltd. (Tianjin, China).

\subsection{Instruments and conditions}

UHPLC-Q-TOF-MS/MS analysis was performed on a Nexera-X2 UHPLC system (Shimadzu Corp., Kyoto, Japan), which was combined with a triple TOF $5600^{+} \mathrm{MS} / \mathrm{MS}$ system (AB SCIEX, Concord, Ontario, Canada). The chromatographic separation was achieved on a Poroshell $120 \mathrm{EC}^{-\mathrm{C}_{18}}$ column $(2.1 \times 100 \mathrm{~mm}$, $2.7 \mu \mathrm{m}$ ) equipped with a Poroshell 120 EC-C18 UHPLC guard column (Agilent Corp, Santa Clara, CA, USA).

The mobile phase was composed of $0.1 \%$ aqueous formic acid (eluent A) and acetonitrile (eluent B). The gradient elution programme was as follows: $5-17 \%$ B from 0 to $10 \mathrm{~min}, 17-35 \%$ B from 10 to $15 \mathrm{~min}, 35-95 \%$ B from 15 to $20 \mathrm{~min}$, and 95\% B held from 20 to $25 \mathrm{~min}$. The injection volume and the flow rate were set at $3 \mu \mathrm{L}$ and $0.3 \mathrm{~mL} \mathrm{~min}{ }^{-1}$, respectively. Equilibration was performed for $3 \mathrm{~min}$ before the next injection. The column temperature remained at $25{ }^{\circ} \mathrm{C}$, and the autosampler tray temperature was maintained at $4{ }^{\circ} \mathrm{C} .{ }^{19}$

Mass spectrometric detection was carried out by a Triple TOF $^{\mathrm{TM}} 5600$ system equipped with Duo-Spray ${ }^{\mathrm{TM}}$ ion sources in the negative electrospray ionization (ESI) mode. The following mass spectrometry parameter settings were used: ion spray voltage (IS), $-4.5 \mathrm{kV}$; turbo spray temperature, $550{ }^{\circ} \mathrm{C}$; optimized declustering potential (DP), $-60 \mathrm{~V}$; collision energy (CE), $-10 \mathrm{eV}$; collision energy spread (CES), $15 \mathrm{eV}$; nebulizing gas (GAS1), 55 psi; heating gas (GAS2), 55 psi; and curtain gas, 35 psi.

\subsection{Metabolism in vivo}

2.3.1. Animals and drug administration. Eighteen male Sprague-Dawley rats (certificate no. 1804195, weighing $220 \pm$ $20 \mathrm{~g}, 12-14$ weeks old) were purchased from the Experimental
Animal Research Center of Hebei Medical University (SCXK 2018-004). All the protocols and procedures for animal handling were carried out following the guidelines of the Hebei committee for care and use of laboratory animals, and were approved by the Animal Experimentation Ethics Committee of the Hebei Medical University (Hebei, China). The conditions of temperature $\left(22-25{ }^{\circ} \mathrm{C}\right)$, humidity $(55-60 \%)$ and light $(12 \mathrm{~h}$ light/dark cycle) were standard for the 8 days prior to use. All rats were fasted but allowed water for $12 \mathrm{~h}$ before the experiments. These rats were randomly divided into six groups with three rats per group. Groups 1, 3 and 5 were the control groups for blank blood, bile, and urine and faeces, respectively. Groups 2, 4 and 6 were the drug groups for blood, bile, and urine and faeces, respectively. Rats in groups 2,4 , and 6 were given eriocitrin by gavage, which was dissolved in a $0.5 \%$ CMC-Na solution at a dose of $50 \mathrm{mg} \mathrm{kg}^{-1}$. However, the rats in groups 1, 3, and 5 were given the same dose of $0.5 \% \mathrm{CMC}-\mathrm{Na}$ solution with no eriocitrin. All rat experiments were conducted in accordance with the committee's guidelines on the Care and Use of Laboratory Animals.

2.3.2. Bio-sample collection. The plasma sample collection was completed as follows: approximately $300-500 \mu \mathrm{L}$ for each blood sample was collected from the eye canthus of rats into $1.5 \mathrm{~mL}$ heparinized tubes at 0.083, 0.167, 0.25, 0.5, 1, 2, 3, 6, 9, 12 and $24 \mathrm{~h}$ after gavage. Every blood sample was centrifuged immediately at $1920 \times g$ for 5 min to obtain the plasma. After that, all collected plasma samples were consolidated and stored at $-80{ }^{\circ} \mathrm{C}$.

Bile collection. To anaesthetize the rats, each rat was intraperitoneally injected with 1-2 $\mathrm{mL}$ of a $20 \%$ urethane solution after gavage. Then, the rats were subjected to bile duct cannulation, and the bile samples were collected during $0-1 \mathrm{~h}, 1-3 \mathrm{~h}$, $3-5 \mathrm{~h}, 5-8 \mathrm{~h}, 8-12 \mathrm{~h}, 12-20 \mathrm{~h}$ and $20-24 \mathrm{~h}$ after gavage with PE10 tubes. $^{20,21}$ Finally, all bile samples were consolidated and frozen at $-80{ }^{\circ} \mathrm{C}$.

Urine and faeces collection. The rats were placed in separated metabolic cages with free access to purified water, and urine and faeces samples were collected over a 0-72 $\mathrm{h}$ period after gavage. ${ }^{22,23}$ Finally, all urine and faecal samples were separately combined and stored at $-80{ }^{\circ} \mathrm{C}$ before pretreatment was conducted.

2.3.3. Bio-sample pretreatment. All biological samples were treated with two methods: protein precipitation with methanol and liquid-liquid extraction with ethyl acetate. An aliquot of $2 \mathrm{~mL}$ of mixed plasma, bile or urine was taken, and three-fold methanol or ethyl acetate was added to precipitate proteins or extract, respectively. Then, the mixture was vortexed for $5 \mathrm{~min}$ and centrifuged at $21380 \times g$ for $10 \mathrm{~min}$ at $4{ }^{\circ} \mathrm{C}$ to obtain the supernatant, which was collected and dried under nitrogen flow at room temperature.

Dried and powdered faecal samples $(2.0 \mathrm{~g})$ were added to 3fold methanol or ethyl acetate and were ultrasonically extracted for $45 \mathrm{~min}$. Next, samples were centrifuged at $21380 \times g$ for $10 \mathrm{~min}$, and the supernatant was dried under nitrogen gas.

$150 \mu \mathrm{L}$ of acetonitrile was added to the residua above and subjected to ultrasonic treatment for $10 \mathrm{~min}$ and centrifugation at $21380 \times g$ for $10 \mathrm{~min}$ to obtain the supernatant that was 
passed through a $0.22 \mu \mathrm{m}$ millipore filter before injection into the UHPLC-Q-TOF-MS/MS system for analysis. Samples from the control and drug groups were treated the same.

\subsection{Metabolism in vitro by rat liver microsomes}

2.4.1. Phase I metabolism. The representative incubation mixture was assembled in PBS buffer (pH 7.4) with a final volume of $200 \mu \mathrm{L}$ and contained liver microsomal protein $\left(1.0 \mathrm{mg} \mathrm{mL}^{-1}\right)$, eriocitrin $\left(100 \mu \mathrm{mol} \mathrm{L}^{-1}\right), \mathrm{MgCl}_{2}\left(3.3 \mathrm{mmol} \mathrm{L}^{-1}\right)$, and $\beta$-NADPH $\left(1.3 \mathrm{mmol} \mathrm{L}^{-1}\right) .{ }^{24}$ Preincubation was conducted at $37^{\circ} \mathrm{C}$ for $5 \mathrm{~min}$, and $\mathrm{NADPH}$ was subsequently added to start the reaction. After incubation at $37^{\circ} \mathrm{C}$ for an additional $90 \mathrm{~min}$, the reaction was stopped by adding $1 \mathrm{~mL}$ of ethyl acetate. Next, samples were vortexed and centrifuged for 5 and $10 \mathrm{~min}$, respectively, and the organic phase was collected and evaporated under nitrogen gas. After reconstitution in $100 \mu \mathrm{L}$ of acetonitrile, samples were passed through $0.22 \mu \mathrm{m}$ millipore filters and stored at $-20{ }^{\circ} \mathrm{C}$ until analysis. Blank groups underwent incubation without the addition of eriocitrin, the control groups were incubated without the addition of NADPH, and the sample groups, which were carried out in triplicate, underwent the full treatment described above. ${ }^{25}$

2.4.2. Phase II metabolism. The representative incubation mixture was implemented in PBS buffer (pH 7.4) with a final volume of $200 \mu \mathrm{L}$ and contained liver microsomal protein (1.0 mg mL $\left.{ }^{-1}\right)$, eriocitrin $\left(100 \mu \mathrm{mol} \mathrm{L}^{-1}\right), \mathrm{MgCl}_{2}\left(3.3 \mathrm{mmol} \mathrm{L}^{-1}\right)$, and UDPGA $\left(2 \mathrm{mmol} \mathrm{L}^{-1}\right)$. Preincubation was performed at $37^{\circ} \mathrm{C}$ for $20 \mathrm{~min}$; subsequently, UDPGA was added to start the reaction. After incubation at $37{ }^{\circ} \mathrm{C}$ for an additional $1 \mathrm{~h}$, the reaction was stopped by adding $200 \mu \mathrm{L}$ of acetonitrile. Next, samples were vortexed and centrifuged for 5 and $10 \mathrm{~min}$, respectively. Finally, the supernatant was passed through a 0.22 $\mu \mathrm{m}$ millipore filter before injection into the UHPLC-Q-TOF-MS/ MS system for analysis. Blank groups were incubated without the addition of eriocitrin, the control groups were incubated without the addition of UDPGA, and the sample groups, which were carried out in triplicate, underwent the treatment described above.

\subsection{Metabolism in vitro by rat intestinal flora}

2.5.1. Preparation of anaerobic culture medium. Solution A: $\mathrm{K}_{2} \mathrm{HPO}_{4}(0.78 \%), 37.5 \mathrm{~mL}$; solution B: $\mathrm{KH}_{2} \mathrm{PO}_{4}(0.47 \%), \mathrm{NaCl}$ (1.18\%), $\left(\mathrm{NH}_{4}\right)_{2} \mathrm{SO}_{4}(1.2 \%), \mathrm{CaCl}_{2}(0.12 \%)$ and $\mathrm{MgSO}_{4}(0.25 \%)$, $37.5 \mathrm{~mL}$; solution C: $\mathrm{Na}_{2} \mathrm{CO}_{3}(8 \%), 50 \mathrm{~mL}$; solution D: L-ascorbic acid (25\%) $2 \mathrm{~mL}$ together with L-cysteine $0.5 \mathrm{~g}$, eurythrol $1 \mathrm{~g}$, tryptone $1 \mathrm{~g}$ and nutrient agar $1 \mathrm{~g}$, brought to $1 \mathrm{~L}$ with ultrapure water. $\mathrm{HCl}\left(1 \mathrm{~mol} \mathrm{~L}^{-1}\right)$ was used to adjust the $\mathrm{pH}$ of the solution to $7.5-8.0$.

2.5.2. Preparation of intestinal flora culture solution. Fresh intestinal contents ( $3 \mathrm{~g}$ ) taken from SD rats were mixed with anaerobic culture medium $(30 \mathrm{~mL})$ immediately. After stirring with a glass rod, the samples were filtered with gauze to obtain the intestinal bacterial liquid.

2.5.3. Sample preparation. Eriocitrin $\left(1 \mathrm{mg} \mathrm{mL}^{-1}, 100 \mu \mathrm{L}\right)$ was added to $1 \mathrm{~mL}$ of intestinal flora culture medium, which was saturated with nitrogen to remove oxygen. After incubation for $6 \mathrm{~h}$, the reactions were terminated by adding 3 volumes of methanol. Then, the mixtures were vortexed for $5 \mathrm{~min}$ and centrifuged at $21380 \times g$ for $10 \mathrm{~min}$. The organic phase was collected and evaporated under nitrogen gas, reconstituted in $100 \mu \mathrm{L}$ of acetonitrile, and vortexed and centrifuged again for 5 and $10 \mathrm{~min}$, respectively. The supernatant was passed through a $0.22 \mu \mathrm{m}$ millipore filter before analysis. Blank groups were incubated without eriocitrin, while the control groups were incubated not in intestinal flora culture solution but in anaerobic culture medium, and sample groups were treated as described above.

\section{Results and discussion}

\subsection{Analytical strategy}

In this study, an efficient UHPLC-Q-TOF-MS/MS strategy was adopted to systematically identify the metabolites of eriocitrin in vivo and in vitro. The strategy was segmented into three steps: first, online full scan data acquisition was performed utilizing MMDF and DBS settings and the MS/MS spectrum of eriocitrin metabolites to collect data. Next, multiple data processing techniques were adopted by using PeakView 1.2 and MetabolitePilot 2.0.4 software, which contained many data-processing tools, such as XIC, MDF, PIF and NIF, and provided accurate MS/MS information to infer and identify the metabolites of eriocitrin. Finally, numerous metabolites were identified on the basis of accurate mass datasets, specific secondary mass spectrometry information and so on. With regard to the isomers of metabolites, $\operatorname{clog} P$ values calculated by ChemDraw 14.0 were used to further distinguish them. In general, the larger the $\operatorname{cog} P$ value, the longer the retention time will be in the reversed-phase chromatography system. ${ }^{\mathbf{2 6 - 3 0}}$

According to the above method, a total of 32 metabolites in vivo and 27 metabolites in vitro (12 metabolites in rat liver microsomes and 20 metabolites in rat intestinal flora) were identified and are shown in Tables 1, 2 and 3, respectively. In addition, the structures of all metabolites are presented in Fig. 2. Their XICs are shown in Fig. 3.

\subsection{Mass fragmentation behaviour of eriocitrin}

To identify the metabolites of eriocitrin, it is important to understand the pyrolysis of the parent drug (M0). Eriocitrin $\left(\mathrm{C}_{27} \mathrm{H}_{32} \mathrm{O}_{15}\right)$ eluted at $12.46 \mathrm{~min}$ and yielded the $[\mathrm{M}-\mathrm{H}]^{-}$ion at 595.1669, and the mass deviation was $0.2 \mathrm{ppm}$ under the chromatographic conditions. The main characteristic fragment ions of M0, seen at $\mathrm{m} / \mathrm{z} 459.1128,287.0552,193.0125,163.0474$, 151.0028, 135.0440 and 125.0233, were detected according to the MS/MS spectrum. The typical fragment ions generated by eriocitrin at $\mathrm{m} / \mathrm{z} 459.1128$ and 287.0552 were attributed to the loss of $\mathrm{C}_{7} \mathrm{H}_{4} \mathrm{O}_{3}$ and $\mathrm{C}_{12} \mathrm{H}_{20} \mathrm{O}_{9}$, respectively. The ion at $\mathrm{m} / \mathrm{z}$ 287.0552 produced a series of representative fragment ions at $\mathrm{m} / \mathrm{z} 193.0125,163.0474$ and 125.0233 by the loss of $\mathrm{CH}_{2} \mathrm{O}_{5}$, $\mathrm{C}_{6} \mathrm{H}_{4} \mathrm{O}_{3}$ and $\mathrm{C}_{9} \mathrm{H}_{6} \mathrm{O}_{3}$, respectively. In addition, the product ions at $m / z 151.0028$ and 135.0440 were formed because of the RDA reaction in ring $\mathrm{C}$ of the flavonoid. The MS/MS spectrum and the fragmentation pathways of eriocitrin are shown in Fig. 1. 


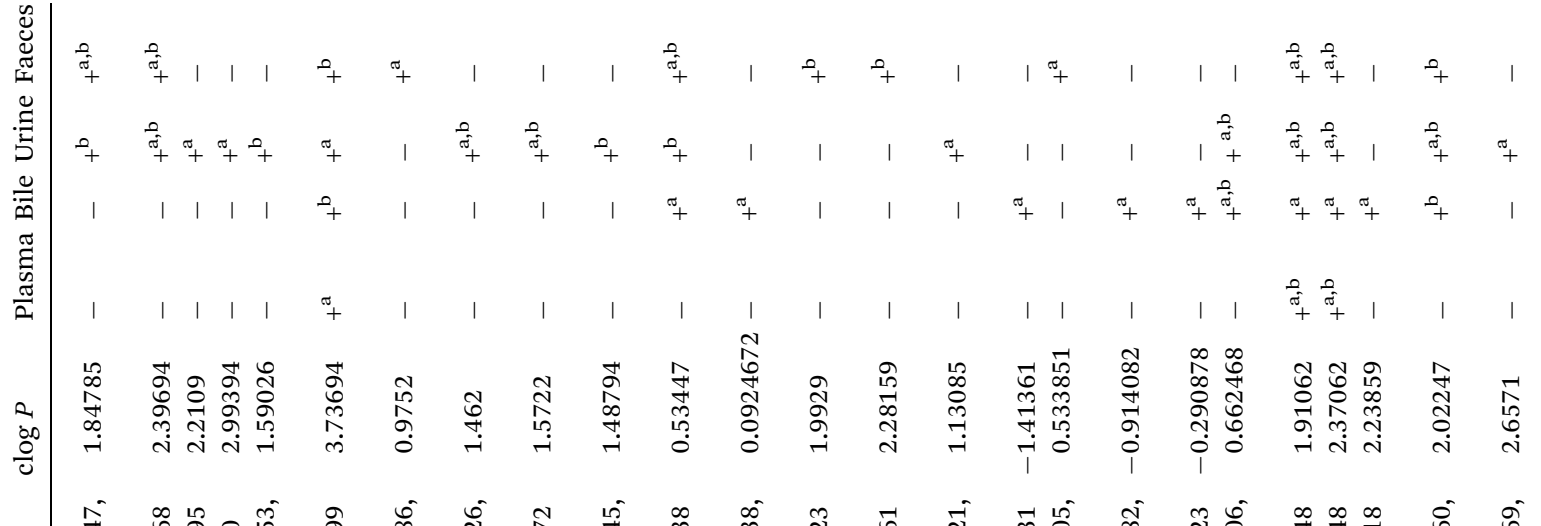

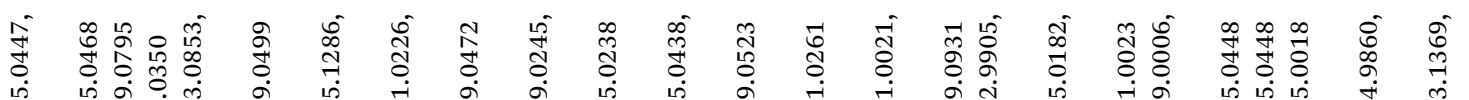
ம்

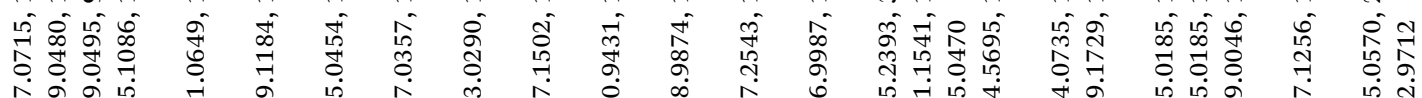

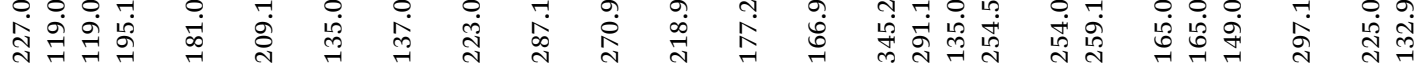

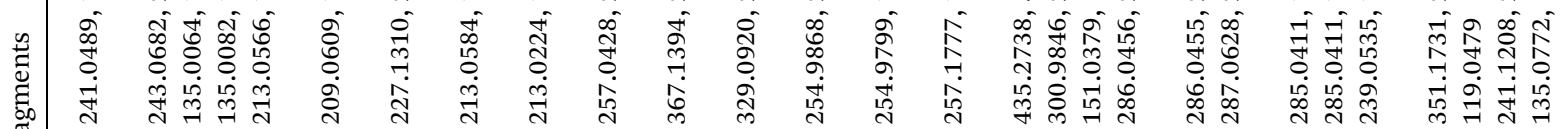

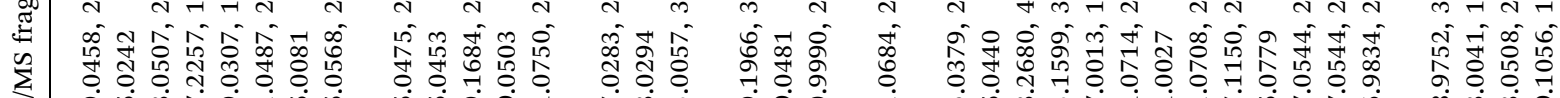

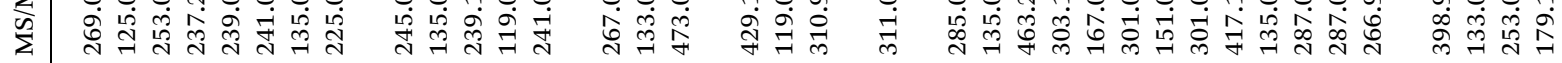

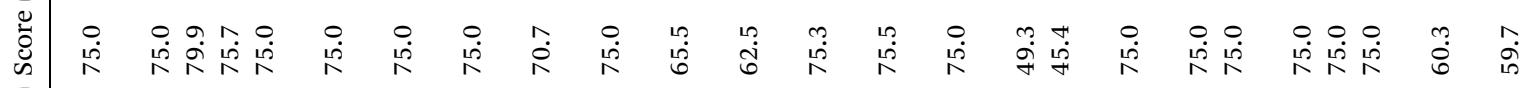

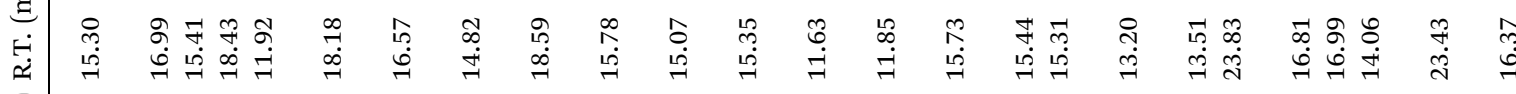

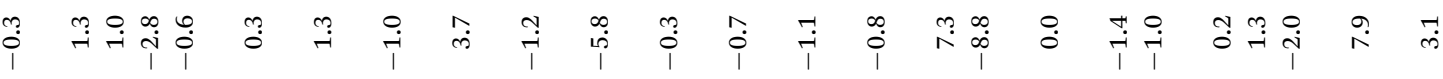

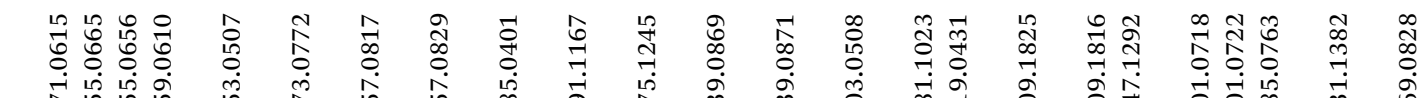

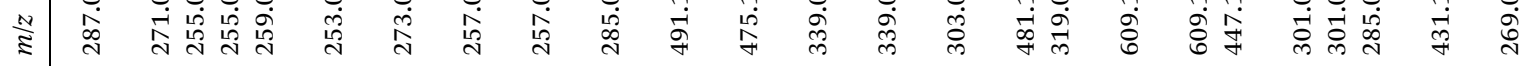

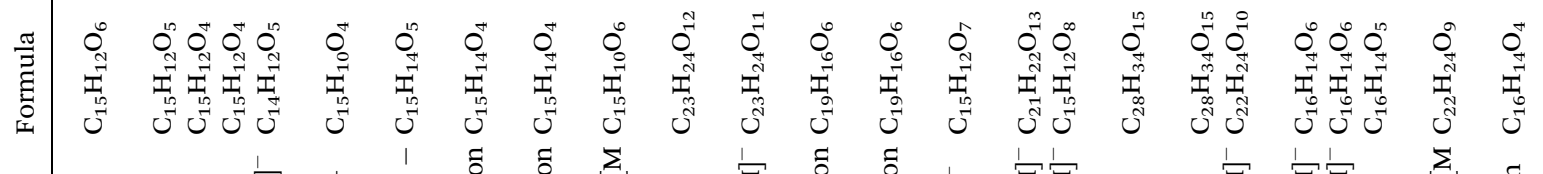

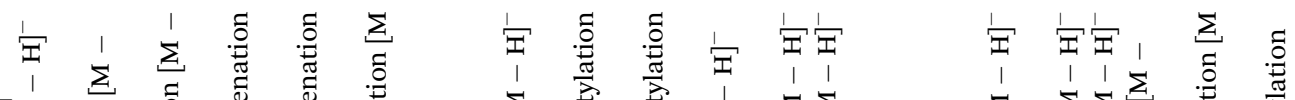

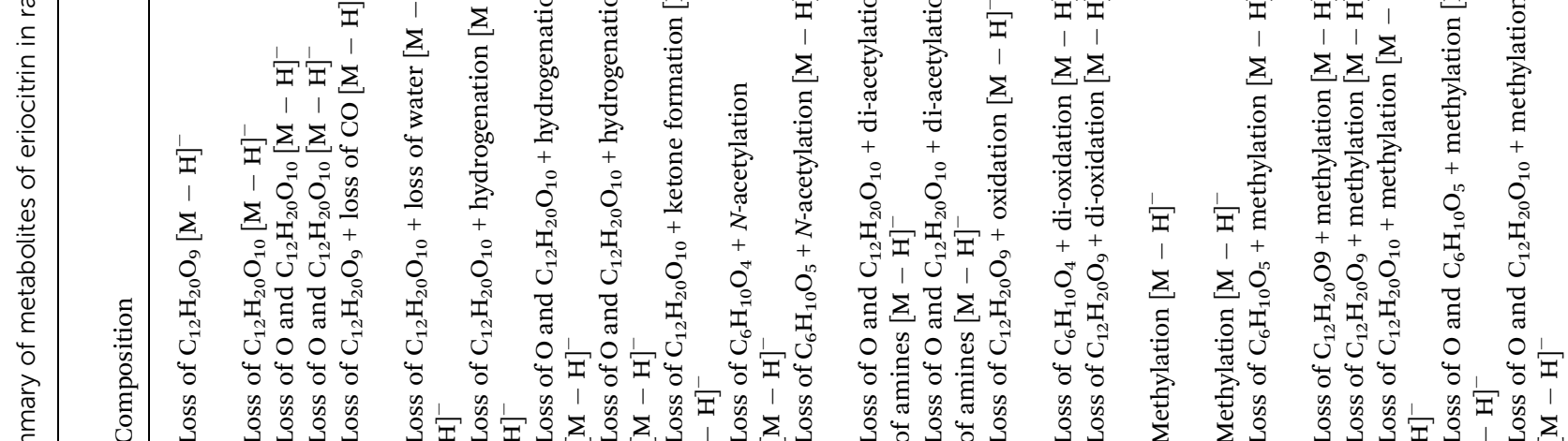




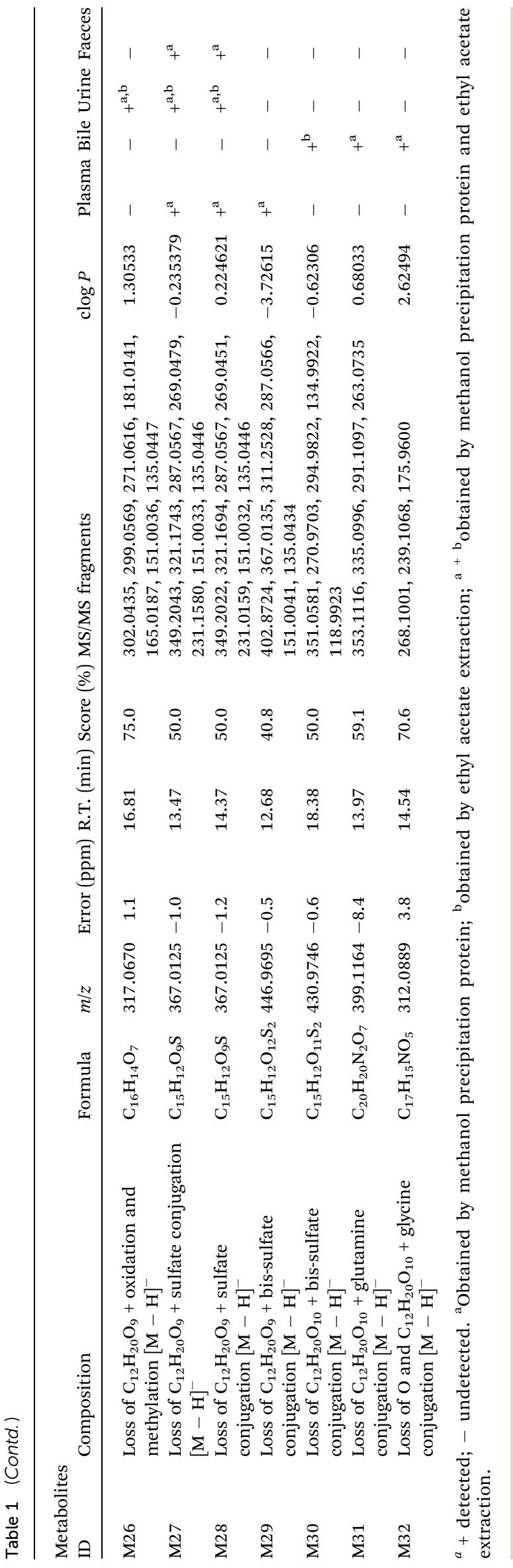

\subsection{Identification of metabolites in vivo}

Metabolite M1 $\left(\mathrm{C}_{15} \mathrm{H}_{12} \mathrm{O}_{6}\right)$ eluted at $15.30 \mathrm{~min}$ and had a deprotonated molecular ion $[\mathrm{M}-\mathrm{H}]^{-}$at $\mathrm{m} / \mathrm{z} 287.0560,308 \mathrm{Da}$ $\left(\mathrm{C}_{12} \mathrm{H}_{20} \mathrm{O}_{9}\right)$ lower than that of the parent drug. The crucial fragment ions of $\mathrm{M} 1$ at $m / z 269.0458\left(\left[\mathrm{M}-\mathrm{H}_{2} \mathrm{O}-\mathrm{H}\right]^{-}\right), m / z$ $241.0489\left(\left[\mathrm{M}-\mathrm{H}_{2} \mathrm{O}-\mathrm{CO}-\mathrm{H}\right]^{-}\right), m / z 151.0032$ (RDA reaction) and $m / z 135.0447$ (RDA reaction) were detected according to the secondary mass spectrum of M1.

Metabolite M2 $\left(\mathrm{C}_{15} \mathrm{H}_{12} \mathrm{O}_{5}\right)$ was identified with a peak at $\mathrm{m} / \mathrm{z}$ 271.0615 in the UPLC system, which eluted at $16.99 \mathrm{~min}$ and was $324 \mathrm{Da}\left(\mathrm{C}_{12} \mathrm{H}_{20} \mathrm{O}_{10}\right)$ lower than that of M0. Based on the MS/ MS information, the typical fragment ions of M2 at $\mathrm{m} / z 253.0507$ $\left(\left[\mathrm{M}-\mathrm{H}_{2} \mathrm{O}-\mathrm{H}\right]^{-}\right), m / z 243.0682\left([\mathrm{M}-\mathrm{CO}-\mathrm{H}]^{-}\right), m / z 227.0715$ ([M$\mathrm{CO}-\mathrm{O}-\mathrm{H}]^{-}$) and $m / z 135.0447$ (RDA reaction) were observed.

Metabolites M3 and M4 $\left(\mathrm{C}_{15} \mathrm{H}_{12} \mathrm{O}_{4}\right)$ are isomers with the deprotonated molecular ions $[\mathrm{M}-\mathrm{H}]^{-}$at $\mathrm{m} / \mathrm{z} 255.0665$ and 255.0656, which were 16 Da (O) lower than that of M2. They eluted at $15.41 \mathrm{~min}$ and $18.43 \mathrm{~min}$, respectively. Based on the secondary fragment ions of $[\mathrm{M}-\mathrm{H}]^{-}$at $m / z 237.2257\left(\left[\mathrm{M}-\mathrm{H}_{2} \mathrm{O}-\right.\right.$ $\left.\mathrm{H}]^{-}\right)$and $109.0795\left(\left[\mathrm{M}-\mathrm{C}_{9} \mathrm{H}_{6} \mathrm{O}_{2}-\mathrm{H}\right]^{-}\right)$generated by $\mathrm{M} 3$, the $\mathrm{B}-$ ring remained the adjacent hydroxyl group, and the loss of $\mathrm{O}$ occurred at C-5 in ring A. Moreover, the clog $P$ values of M3 and M4 were 2.2109 and 2.99394, respectively, aiding in their verification.

Metabolite $\mathrm{M} 5\left(\mathrm{C}_{14} \mathrm{H}_{12} \mathrm{O}_{5}\right)$ eluted at $\mathbf{1 1 . 9 2} \mathrm{min}$ and displayed a deprotonated molecular ion $[\mathrm{M}-\mathrm{H}]^{-}$at $m / z 259.0610,28 \mathrm{Da}$ (CO) lower than that of M1. In its secondary mass spectrum, the diagnostic fragment ions produced by M5 at $m / z 241.0487$ ([M$\left.\left.\mathrm{H}_{2} \mathrm{O}-\mathrm{H}\right]^{-}\right), m / z 213.0566\left(\left[\mathrm{M}-\mathrm{H}_{2} \mathrm{O}-\mathrm{CO}-\mathrm{H}\right]^{-}\right), m / z 195.1086([\mathrm{M}-$ $\left.4 \mathrm{O}-\mathrm{H}]^{-}\right), m / z 183.0853\left([\mathrm{M}-3 \mathrm{O}-\mathrm{CO}-\mathrm{H}]^{-}\right)$and $m / z 135.0081$ (RDA reaction) were observed.

Metabolite M6 $\left(\mathrm{C}_{15} \mathrm{H}_{10} \mathrm{O}_{4}\right)$ had a deprotonated molecular ion $[\mathrm{M}-\mathrm{H}]^{-}$at $m / z 253.0507$ and observed at the retention time of $18.18 \mathrm{~min}$, which was $18 \mathrm{Da}\left(\mathrm{H}_{2} \mathrm{O}\right)$ lower than that of M2. M6 contained representative fragment ions at $m / z 225.0568$ ([M$\left.\mathrm{CO}-\mathrm{H}]^{-}\right), m / z 209.0609\left(\left[\mathrm{M}-\mathrm{CO}_{2}-\mathrm{H}\right]^{-}\right)$and $m / z 181.0649$ ([M$\left.\mathrm{CO}_{2}-\mathrm{CO}-\mathrm{H}\right]^{-}$) in its secondary mass spectrum. Moreover, the noteworthy fragment ion at $\mathrm{m} / \mathrm{z} 119.0499$ was created by the loss of $\mathrm{O}$ through the RDA reaction of $\mathrm{M} 6$.

Metabolite $\mathrm{M} 7\left(\mathrm{C}_{15} \mathrm{H}_{14} \mathrm{O}_{5}\right)$ eluted at $16.57 \mathrm{~min}$ with the deprotonated molecular ion $[\mathrm{M}-\mathrm{H}]^{-}$at $m / z$ 273.0772, which was $2 \mathrm{Da}(2 \mathrm{H})$ higher than M2. Crucial fragment ions at $\mathrm{m} / \mathrm{z}$ 245.0475, 227.1310, 209.1184, 165.1286 and 135.0453 were produced by the loss of $\mathrm{CO}, \mathrm{CH}_{2} \mathrm{O}_{2}, 4 \mathrm{O}, \mathrm{C}_{6} \mathrm{H}_{4} \mathrm{O}_{2}$ and the RDA reaction, respectively.

Metabolites M8 and M9 $\left(\mathrm{C}_{15} \mathrm{H}_{14} \mathrm{O}_{4}\right)$ eluted at $14.82 \mathrm{~min}$ and $18.59 \mathrm{~min}$, respectively, with deprotonated molecular ions [M $\mathrm{H}]^{-}$at $m / z 257.0817$ and 257.0829, which were $2 \mathrm{Da}(2 \mathrm{H})$ higher than M3 and M4. The representative fragment ions at $\mathrm{m} / \mathrm{z}$ 239.1684, 135.0454 and 121.0226 were generated by M8, implying that the loss of $\mathrm{O}$ occurred in ring A. Similarly, the prominent fragment ions of metabolite M9 at $\mathrm{m} / \mathrm{z} 137.0357$ and 119.0472 indicated that the loss of $\mathrm{O}$ occurred in the B ring. Furthermore, the $\operatorname{clog} P$ values of M8 and M9 were 1.462 and 1.5722, respectively, so their structural identities were confirmed. 


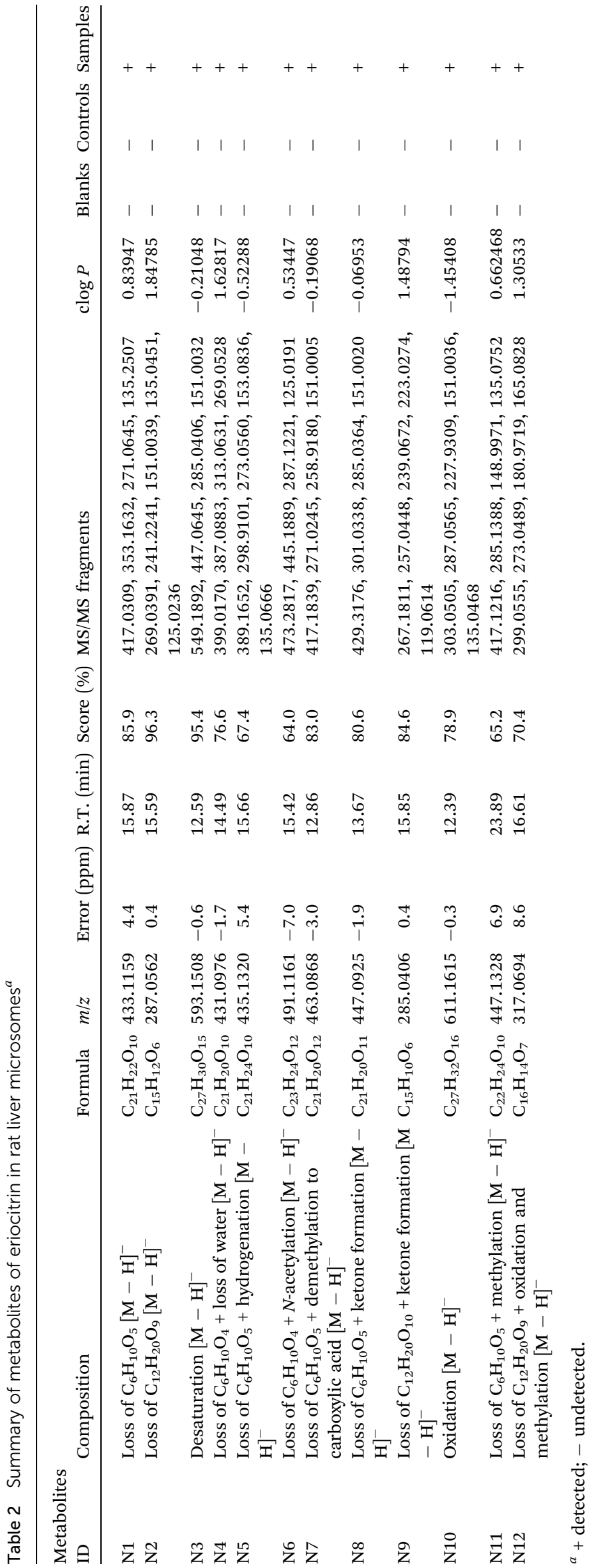




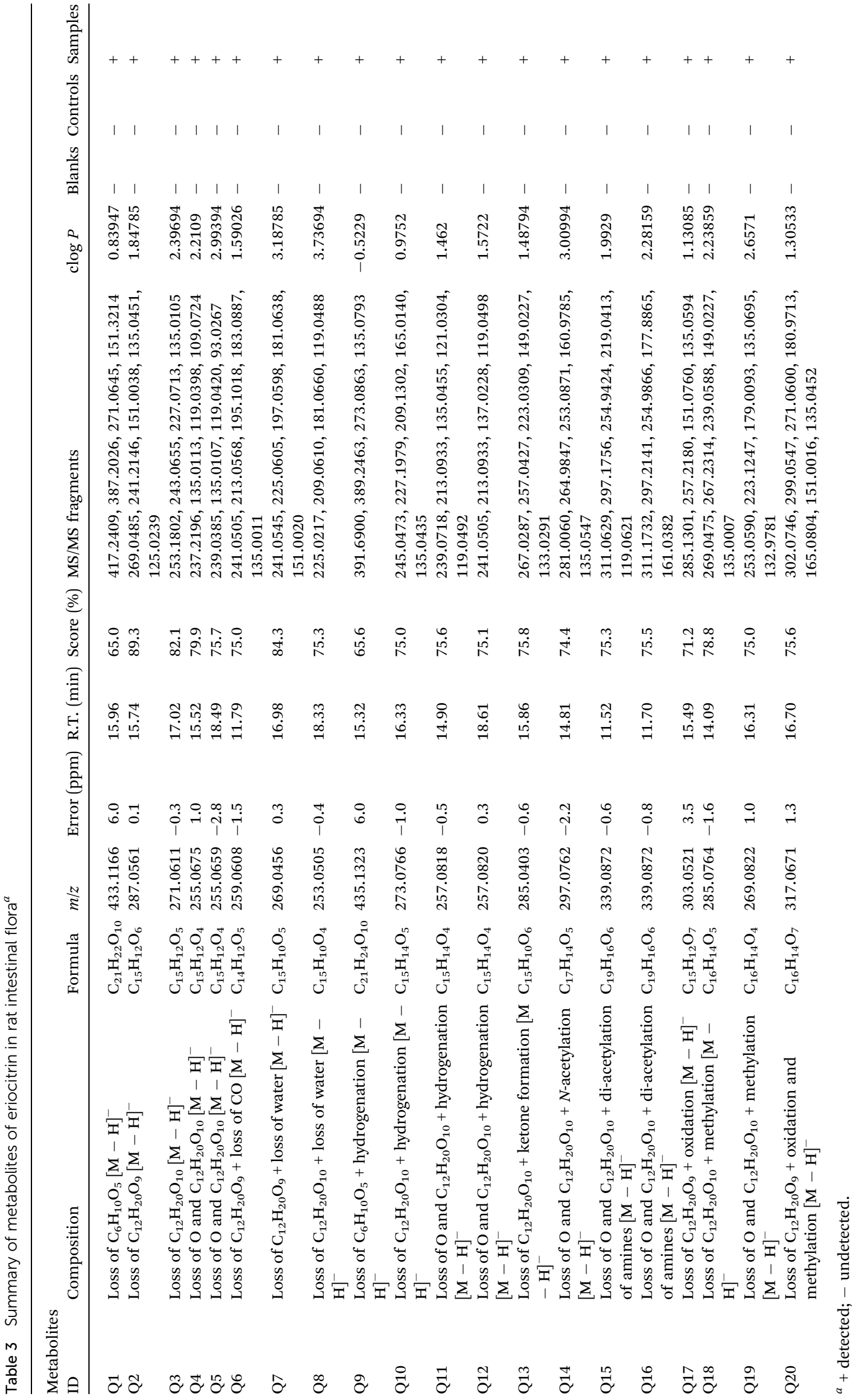



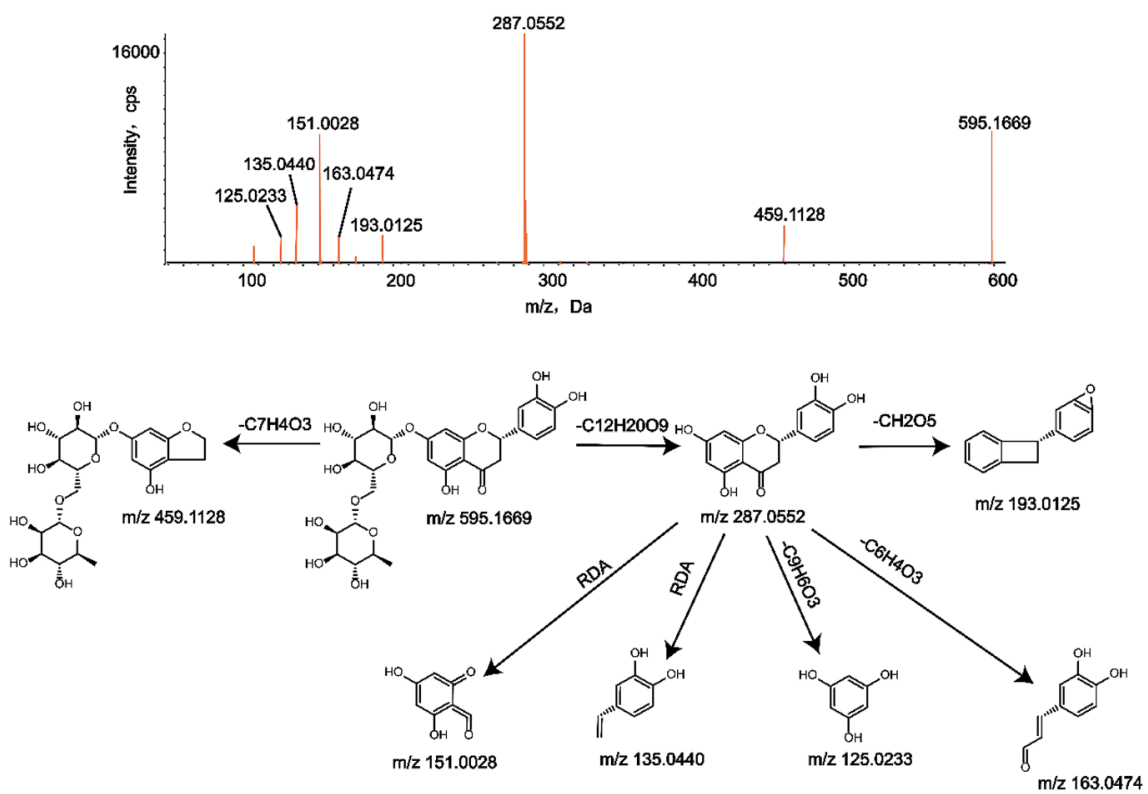

Fig. 1 MS/MS spectrum of eriocitrin and its predominant fragmentation pathways.

Metabolite M10 $\left(\mathrm{C}_{15} \mathrm{H}_{10} \mathrm{O}_{6}\right)$ eluted at $15.78 \mathrm{~min}$ and exhibited the deprotonated molecular ion $[\mathrm{M}-\mathrm{H}]^{-}$at $\mathrm{m} / \mathrm{z} 285.0401$, which was $14 \mathrm{Da}$ higher than that of M2. The characteristic fragment ions of $\mathrm{M} 10$ at $m / z 267.0283\left(\left[\mathrm{M}-\mathrm{H}_{2} \mathrm{O}-\mathrm{H}\right]^{-}\right), 257.0428$ $\left([\mathrm{M}-\mathrm{CO}-\mathrm{H}]^{-}\right), 223.0290\left(\left[\mathrm{M}-\mathrm{H}_{2} \mathrm{O}-\mathrm{CO}-\mathrm{O}-\mathrm{H}\right]^{-}\right)$and 149.0245 (RDA reaction) were obtained according to the MS/MS information.

Metabolite M11 $\left(\mathrm{C}_{23} \mathrm{H}_{24} \mathrm{O}_{12}\right)$ eluted at $15.07 \mathrm{~min}$ and displayed the deprotonated molecular ion $[\mathrm{M}-\mathrm{H}]^{-}$at $\mathrm{m} / \mathrm{z}$ 491.1167, 104 Da lower than that of the parent drug. M11 had typical fragment ions at $m / z \quad 473.0057\left(\left[\mathrm{M}-\mathrm{H}_{2} \mathrm{O}-\mathrm{H}\right]^{-}\right), m / z$ $367.1394\left(\left[\mathrm{M}-\mathrm{C}_{6} \mathrm{H}_{4} \mathrm{O}_{3}-\mathrm{H}\right]^{-}\right), m / z 287.1502\left(\left[\mathrm{M}-\mathrm{C}_{8} \mathrm{H}_{12} \mathrm{O}_{6}-\mathrm{H}\right]^{-}\right)$, and $m / z 125.0238\left(\left[\mathrm{M}-\mathrm{C}_{17} \mathrm{H}_{18} \mathrm{O}_{9}-\mathrm{H}\right]^{-}\right)$, as seen in the secondary mass spectrum.

Metabolite M12 $\left(\mathrm{C}_{23} \mathrm{H}_{24} \mathrm{O}_{11}\right)$ was detected at a retention time of 15.35 min with the deprotonated molecular ion $[\mathrm{M}-\mathrm{H}]^{-}$at $m / z 475.1245,120$ Da lower than that of eriocitrin, which exhibited the characteristic fragment ions at $\mathrm{m} / \mathrm{z} 429.1966$ ([M$\left.\left.\mathrm{CO}-\mathrm{H}_{2} \mathrm{O}-\mathrm{H}\right]^{-}\right), m / z 329.0920\left(\left[\mathrm{M}-\mathrm{C}_{6} \mathrm{H}_{10} \mathrm{O}_{4}-\mathrm{H}\right]^{-}\right), \mathrm{m} / z 270.9431$ $\left(\left[\mathrm{M}-\mathrm{C}_{6} \mathrm{H}_{4} \mathrm{O}_{2}-\mathrm{C}_{2} \mathrm{H}_{2} \mathrm{O}_{2}-\mathrm{H}\right]^{-}\right.$) and $m / z 135.0438$ (RDA reaction) in the MS/MS information.

Metabolites M13 and M14 $\left(\mathrm{C}_{19} \mathrm{H}_{16} \mathrm{O}_{6}\right)$ eluted at $11.63 \mathrm{~min}$ and $11.85 \mathrm{~min}$, respectively, with the deprotonated molecular ions $[\mathrm{M}-\mathrm{H}]^{-}$at $m / z 339.0869$ and 339.0871 , which were $84 \mathrm{Da}$ higher than those of M3 and M4, implying that the diacetylation reaction occurred based on the loss of $\mathrm{O}$ and $\mathrm{C}_{12} \mathrm{H}_{20} \mathrm{O}_{10}$. According to the fragment ions at $\mathrm{m} / \mathrm{z} 218.9874$ and 119.0523 acquired after the RDA reaction, the loss of $\mathrm{O}$ occurred in the $\mathrm{A}$ ring, while the diacetylation occurred in the B ring. Similarly, the fragment ions at $\mathrm{m} / \mathrm{z} 177.0911$ and 161.0237 indicated that the loss of $\mathrm{O}$ occurred in ring $\mathrm{B}$ and diacetylation occurred in both rings A and B. Therefore, the structures of metabolites M13 and M14, which are isomers of each other, were determined. In addition, they were also validated with $\operatorname{cog} P$ values of M13 and M14, which were 1.9929 and 2.28159, respectively.
Metabolite M15 $\left(\mathrm{C}_{15} \mathrm{H}_{12} \mathrm{O}_{7}\right)$ was detected at 15.73 min and showed the deprotonated molecular ion $[\mathrm{M}-\mathrm{H}]^{-}$at $\mathrm{m} / \mathrm{z}$ 303.0508, $16 \mathrm{Da}(\mathrm{O})$ higher than that of M1, which contained the characteristic fragment ions at $m / z 285.0379\left(\left[\mathrm{M}-\mathrm{H}_{2} \mathrm{O}-\mathrm{H}\right]^{-}\right), m / z$ $257.1777\left(\left[\mathrm{M}-\mathrm{CO}-\mathrm{H}_{2} \mathrm{O}-\mathrm{H}\right]^{-}\right), m / z 151.0021$ (RDA reaction) and $\mathrm{m} / \mathrm{z} 135.0440$ (RDA reaction) according to the secondary mass spectrum.

Metabolite M16 $\left(\mathrm{C}_{21} \mathrm{H}_{22} \mathrm{O}_{13}\right)$ exhibited an $[\mathrm{M}-\mathrm{H}]^{-}$ion of $\mathrm{m} / \mathrm{z}$ 481.1023 that eluted at $15.44 \mathrm{~min}$ and was 114 Da lower than that of M0. According to its secondary mass spectrum, the characteristic fragment ions produced at $\mathrm{m} / \mathrm{z} 463.2680$ ([M$\left.\mathrm{H}_{2} \mathrm{O}-\mathrm{H}\right]^{-}$), $m / z 435.2738\left(\left[\mathrm{M}-\mathrm{CO}-\mathrm{H}_{2} \mathrm{O}-\mathrm{H}\right]^{-}\right.$), $m / z$ 345.2393 (RDA reaction) and $m / z 319.0931\left(\left[\mathrm{M}-\mathrm{C}_{6} \mathrm{H}_{10} \mathrm{O}_{5}-\mathrm{H}\right]^{-}\right)$were observed and identified.

Metabolite $\mathrm{M} 17\left(\mathrm{C}_{15} \mathrm{H}_{12} \mathrm{O}_{8}\right)$ eluted at a retention time of 15.31 min. The MS/MS spectrum showed the deprotonated molecular ion $[\mathrm{M}-\mathrm{H}]^{-}$at $m / z$ 319.0431, which was $32 \mathrm{Da}(2 \mathrm{O})$ higher than that of M1. The metabolite M17 generated characteristic fragment ions at $\mathrm{m} / \mathrm{z} 303.1599,300.9846$ and 291.1541 through losing $\mathrm{O}, \mathrm{H}_{2} \mathrm{O}$, and $\mathrm{CO}$, respectively, and the possible structures of the metabolite M17 were predicted by the characteristic fragment ions at $\mathrm{m} / \mathrm{z} 182.9905,167.0013,151.0379$ and 135.0470 generated by RDA cleavage.

Metabolites M18 and M19 $\left(\mathrm{C}_{28} \mathrm{H}_{34} \mathrm{O}_{15}\right)$ eluted at $13.20 \mathrm{~min}$ and $13.51 \mathrm{~min}$, respectively, showing the deprotonated molecular ions $[\mathrm{M}-\mathrm{H}]^{-}$at $m / z 609.1825$ and 609.1816, which were $14 \mathrm{Da}\left(\mathrm{CH}_{2}\right)$ higher than that of eriocitrin. Metabolites successively lost $\mathrm{C}_{12} \mathrm{H}_{20} \mathrm{O}_{9}, \mathrm{CH}_{3}$, and $2 \mathrm{O}$ and underwent RDA reactions, resulting in crucial product ions at $\mathrm{m} / \mathrm{z}$ 301.0714, 286.0456, 254.5695 and 151.0027. $\operatorname{clog} P$ values of metabolites M18 and M19 were -0.914082 and -0.290878 , respectively, so they were verified.

Metabolite M20 $\left(\mathrm{C}_{22} \mathrm{H}_{24} \mathrm{O}_{10}\right)$ eluted at $23.83 \mathrm{~min}$ and had a deprotonated molecular ion $[\mathrm{M}-\mathrm{H}]^{-}$at $m / z 447.1292,148 \mathrm{Da}$ lower than that of M0. The characteristic fragment ions of M20 
at $m / z 417.1150\left(\left[\mathrm{M}-\mathrm{CH}_{2} \mathrm{O}-\mathrm{H}\right]^{-}\right), m / z 287.0628\left(\left[\mathrm{M}^{-} \mathrm{C}_{6} \mathrm{H}_{10} \mathrm{O}_{4}{ }^{-}\right.\right.$ $\left.\left.\mathrm{CH}_{2}-\mathrm{H}\right]^{-}\right), m / z 259.1729\left(\left[\mathrm{M}-\mathrm{C}_{6} \mathrm{H}_{10} \mathrm{O}_{4}-\mathrm{CH}_{2}-\mathrm{CO}-\mathrm{H}\right]^{-}\right)$and $\mathrm{m} / z$ 149.0006 (RDA reaction) were detected according to its secondary mass spectrum. After RDA cleavage of the metabolite M20, a methoxy group was lost to obtain a secondary fragment ion at $\mathrm{m} / \mathrm{z}$ 135.0779. Hence, the possible metabolites of it were inferred.

Metabolites M21 and M22 $\left(\mathrm{C}_{16} \mathrm{H}_{14} \mathrm{O}_{6}\right)$ eluted at $16.81 \mathrm{~min}$ and $16.99 \mathrm{~min}$, respectively. They had deprotonated molecular ions $[\mathrm{M}-\mathrm{H}]^{-}$at $\mathrm{m} / \mathrm{z} 301.0718$ and 301.0722 , which were $14 \mathrm{Da}\left(\mathrm{CH}_{2}\right)$ higher than that of M1. Characteristic ions at $\mathrm{m} / \mathrm{z} 287.0544$ and
285.0411 were formed through the loss of $\mathrm{CH}_{2}$ and $\mathrm{O}$, respectively. According to the fragment ions at $m / z 165.0185$ and 135.0448 produced by RDA reaction, methylation occurred in the A ring. In addition, they were validated with the $\operatorname{clog} P$ values of M21 and M22, which were 1.91062 and 2.37062, respectively.

Metabolite M23 $\left(\mathrm{C}_{16} \mathrm{H}_{14} \mathrm{O}_{5}\right)$ eluted at $14.06 \mathrm{~min}$ and displayed a deprotonated molecular ion $[\mathrm{M}-\mathrm{H}]^{-}$at $\mathrm{m} / \mathrm{z} 285.0763$, $14 \mathrm{Da}\left(\mathrm{CH}_{2}\right)$ higher than that of $\mathrm{M} 2$. The noteworthy fragment ions at $m / z \quad 149.0046$ and 135.0018 were yielded by RDA cleavage, indicating that methylation occurred at position 5 in ring $\mathrm{A}$, so the structure was determined.

A<smiles></smiles>

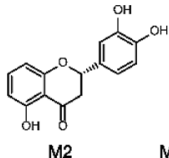<smiles></smiles>

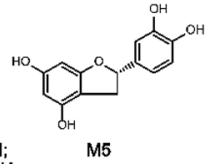<smiles>C1CC2CCCC(C1)C21CCCC1</smiles>

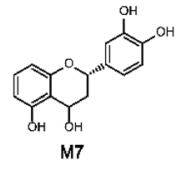<smiles>C1CCC(C2CCCC2)CC1</smiles>

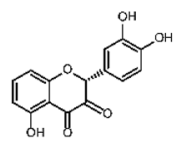

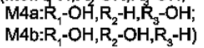

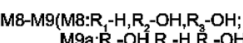
$M 9 a: R_{1}-O H, R_{2}-H_{2}, R_{3}-O H$ $\left.M 9 b: R_{1}-O H, R_{2}-O H, R_{3}-H\right)$

M10<smiles>CC(=O)OC[C@H]1O[C@@H](Oc2cc(O)c3c(c2)O[C@H](c2ccc(C)c(O)c2)CC3=O)[C@H](O)[C@@H](O)[C@@H]1O</smiles>

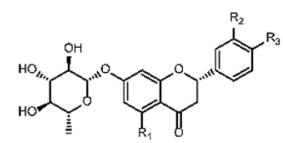

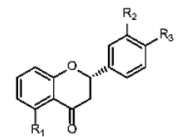

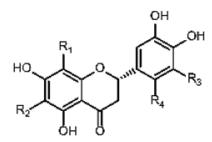

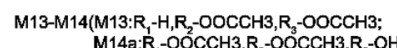
M14a: $R_{1}-O O C C H 3, R_{2}-O O C C H 3, R_{3}-\mathrm{OH}_{1}$
M14b: $\left.R_{1}-O O C C H 3, R_{2}-H, R_{3}-O O C C H 3\right)$

M15a-d(M15a: $\mathbf{R}_{1}-\mathrm{OH}, \mathbf{R}_{2}-\mathrm{H}_{,} \mathbf{R}_{3}-\mathrm{H}_{,}, \mathbf{R}_{4}-\mathbf{H} ;$
M15b:R,-H,

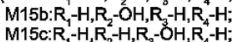
M15d: $\left.R_{1}^{1}-H, R_{2}^{2}-H, R_{3}^{3}-H, R_{4}-O H\right)$

M12a-c(M12a: $\mathrm{R}_{1}-\mathrm{OOCCH}, \mathrm{R}_{2}-\mathrm{OH}, \mathrm{R}_{3}-\mathrm{OH} ;$
M12b: $\mathrm{R}_{1}-\mathrm{OH}, \mathrm{R}_{-}-\mathrm{OOCCH}, \mathrm{R}_{3}-\mathrm{OH} ;$ M12b: $\mathrm{R}_{1}-\mathrm{OH}, \mathrm{R}_{2}-\mathrm{OOCCH}, \mathrm{R}_{3}-\mathrm{OH}_{\text {; }}$
M12c: $\mathrm{R}_{1}-\mathrm{OH}, \mathrm{R}_{2}-\mathrm{OH}, \mathrm{R}_{3}-\mathrm{OOCCH}$ )

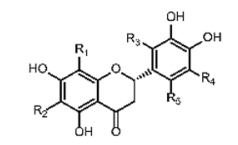

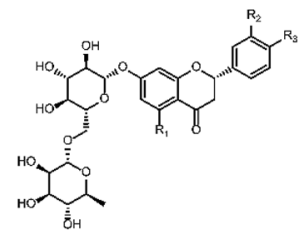<smiles>[2H]c1ccc([C@@H]2CC(=O)c3cc(O[C@@H]4O[C@@H](C)[C@@H](C)[C@H](O)[C@H]4O)ccc3O2)cc1[2H]</smiles><smiles>Cc1cc(O)cc2c1C(=O)CC(c1ccc(O)c(O)c1)O2</smiles>

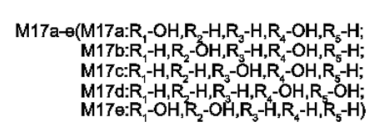

M18-M19(M18: $\mathrm{R}_{-}-\mathrm{OCH}, \mathrm{R}_{2}-\mathrm{OH}, \mathrm{R}_{-}-\mathrm{OH}$;
M19a: $\mathrm{R}_{1}-\mathrm{OH}, \mathrm{R}_{2}-\mathrm{OCH} 3, \mathrm{C}_{3}-\mathrm{OH}$ M19a: $R_{1}-\mathrm{OH}, \mathrm{R}_{2}-\mathrm{OCH} 3, \mathrm{R}_{3}-\mathrm{OH}$;
M19b: $\mathrm{R}_{1}-\mathrm{OH}, \mathrm{R}_{2}-\mathrm{OH}, \mathrm{R}_{2}-\mathrm{OCH} 3$ )

$M 20 a-c\left(M 2 O a: R_{1}-O C H 3, R_{2}-O H, R_{3}-O H ;\right.$
$M 2 O b R_{1}-O H, R_{2}-O C H 3, R_{0}-O H ;$ $M 200 R_{1}-O H, R_{2}-O C H 3, R_{3}-O H ;$
$\left.M 2 O C: R_{1}-O H, R_{2}-O H, R_{3}-O C H 3\right)$

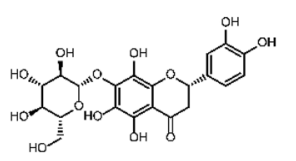

M16<smiles>COc1cc(O)c2c(c1)O[C@@H](c1ccc(O)c(O)c1)CC2=O</smiles><smiles>c1ccc(-c2cnccn2)cc1</smiles>

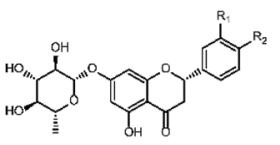
M24a-b(M24a: $R_{1}-O C H 3, R_{2}-H_{i} ;$
$\left.M 24 b: R_{1}-H, R_{2}-O C H 3\right)$ M25a-b(M25a: $\mathrm{R}_{1}-\mathrm{OCH} 3, \mathrm{R}_{2}-\mathrm{OH}$;

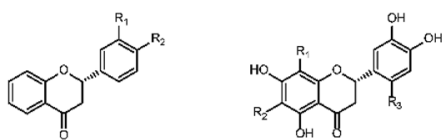

M22

M23

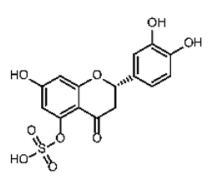

M27

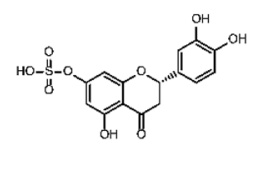

M28

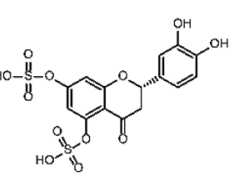

M29

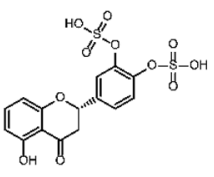

M30

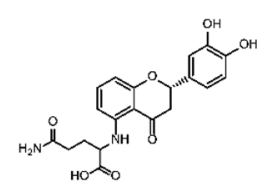

M31

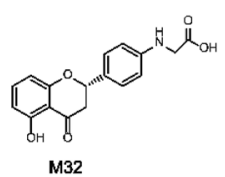

Fig. 2 Structures of all metabolites of eriocitrin in vivo and in vitro ((A) in vivo, (B) in rat liver microsomes, (C) in rat intestinal flora. (a-d) Possible chemical structure). 
B

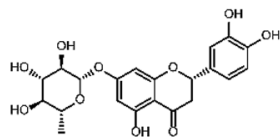<smiles>Cc1ccc(-c2cccc(C)c2)cc1</smiles>

N2

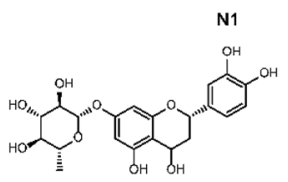

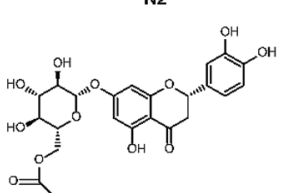

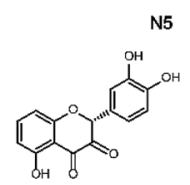

N9

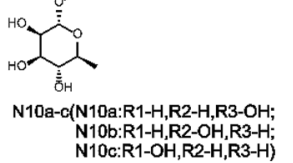

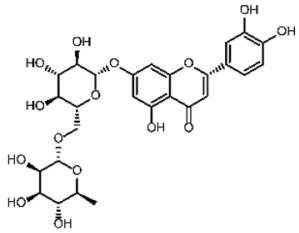

N3

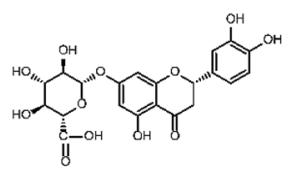

N7

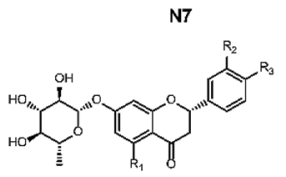

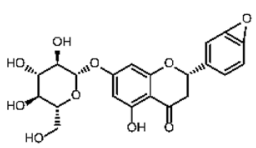

N4

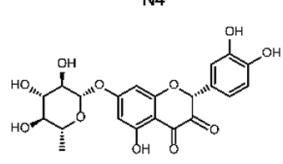

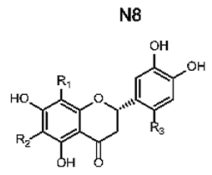

N11a-c(N11a:R1-OCH3,R2-OH,R3-OH;
N11b:R1-OH,R2-OCH3,R3-OH;

N12a-c(N12a:R1-OCH3,R2-H,R3-H; N12b:R1-H,R2-OCH3,R3-H;
N12c:R1-H,R2-H,R3-OCH3)

C

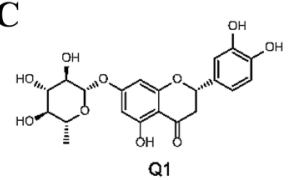<smiles>CC1CC2CCC(CC2)C1C1CCCC1</smiles>

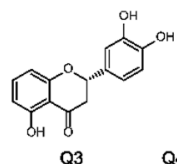

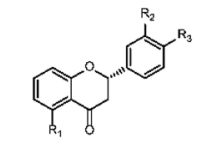
Q4-Q51Q4:R1-H,R2-OH,R3-OH; Q5a:R1-OH,R2-H,R3-OH;
Q5b:R1-OH,R2-OH,R3-H)

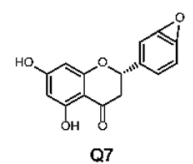<smiles></smiles>

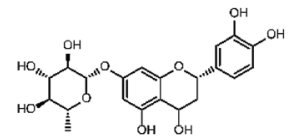<smiles>CCCCOC1CCCC1</smiles>

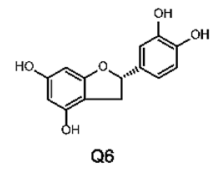

Q6

Q9 Q10

Q11-Q12(Q11:R1-H,R2-OH,R3-OH; Q12a:R1-OH,R2-H,R3-OH;

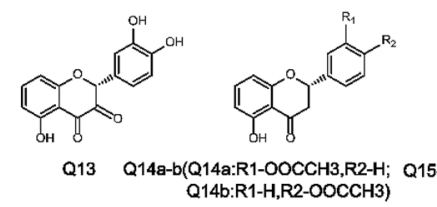

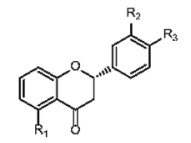

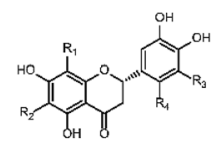

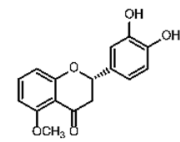
Q14b:R1-H,R2-OOCCH3)

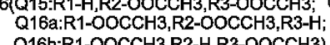
Q166:R1-OOOCCH3,R2-H,R3-OOOCCH3)<smiles>c1ccc(-c2cccn2-c2cccnc2)cc1</smiles>

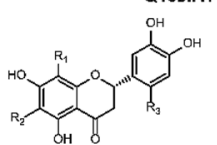

Q19a-b(Q19a:R1-OCH3,R2-OH;

Q20a-c(Q20a:R1-OCH3,R2-H,R3-Hi Q20b:R1-H,R2-OCH3,R3-H;

Fig. 2 (contd.)

Metabolite M24 $\left(\mathrm{C}_{22} \mathrm{H}_{24} \mathrm{O}_{9}\right)$, with a deprotonated molecular ion of $\mathrm{m} / \mathrm{z} 431.1382$ and retention time of $23.43 \mathrm{~min}$, was $164 \mathrm{Da}$ lower than that of M0. The characteristic fragment ions at $\mathrm{m} / \mathrm{z}$ 398.9752, 351.1731, 297.1256 and 133.0041 were formed by the loss of $\mathrm{O}, 5 \mathrm{O}$ and RDA cleavage, while the fragment ions at $\mathrm{m} / \mathrm{z}$ 297.1256 and 133.0041 created the ions at $\mathrm{m} / \mathrm{z} 134.9860$ and 119.0479 via $\mathrm{C}_{6} \mathrm{H}_{10} \mathrm{O}_{5}$ and $\mathrm{CH}_{2}$ loss, respectively. Thus, M24 was illustrated according to the above information.

Metabolite M25 $\left(\mathrm{C}_{16} \mathrm{H}_{14} \mathrm{O}_{4}\right)$ with the $[\mathrm{M}-\mathrm{H}]^{-}$ion of $\mathrm{m} / z$ 269.0828, eluted at $16.37 \mathrm{~min}$ and had a mass $14 \mathrm{Da}\left(\mathrm{CH}_{2}\right)$ higher than that of M3. Secondary fragment ions at $\mathrm{m} / \mathrm{z}$ 253.0508, 223.1369 and 179.1056 were generated by the successive loss of $\mathrm{O}, \mathrm{CH}_{2} \mathrm{O}$ and $\mathrm{CO}_{2}$, while fragment ions at $\mathrm{m} / \mathrm{z}$
241.1208 and 225.0570 were produced by losing CO and O successively. According to the dominant fragment ions at $\mathrm{m} / \mathrm{z}$ 132.9712 and 135.0772 gained by the RDA reaction, both oxygen loss and methylation occurred in the $\mathrm{B}$ ring.

Metabolite M26 $\left(\mathrm{C}_{16} \mathrm{H}_{14} \mathrm{O}_{7}\right)$ was detected at $16.81 \mathrm{~min}$ and displayed a deprotonated molecular ion $[\mathbf{M}-\mathrm{H}]^{-}$at $\mathrm{m} / \mathrm{z}$ 317.0670, $30 \mathrm{Da}\left(\mathrm{CH}_{2} \mathrm{O}\right)$ higher than that of $\mathrm{M} 1$. Based on the MS/MS spectrum, M26 contained characteristic fragment ions at $m / z 302.0435\left(\left[\mathrm{M}-\mathrm{CH}_{3}-\mathrm{H}\right]^{-}\right), 299.0569\left(\left[\mathrm{M}-\mathrm{H}_{2} \mathrm{O}-\mathrm{H}\right]^{-}\right)$, and $271.0616\left(\left[\mathrm{M}-\mathrm{CH}_{2} \mathrm{O}-\mathrm{O}-\mathrm{H}\right]^{-}\right)$, and the possible structures of $\mathrm{M} 26$ could be inferred by combining the evaluation with the fragment ions at $\mathrm{m} / \mathrm{z} 181.0141,165.0187,151.0036$ and 135.0447 caused by RDA reaction. 
D1

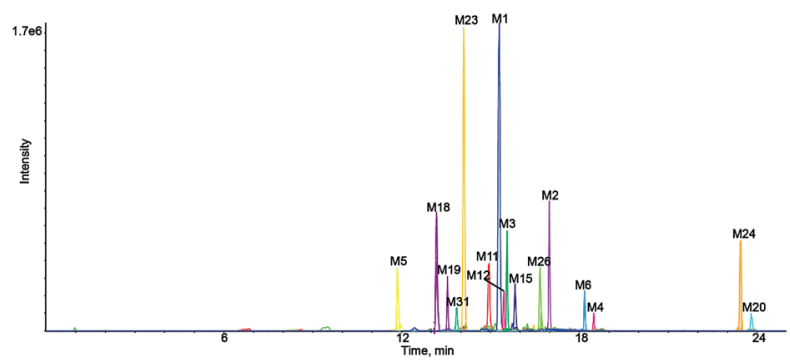

D2

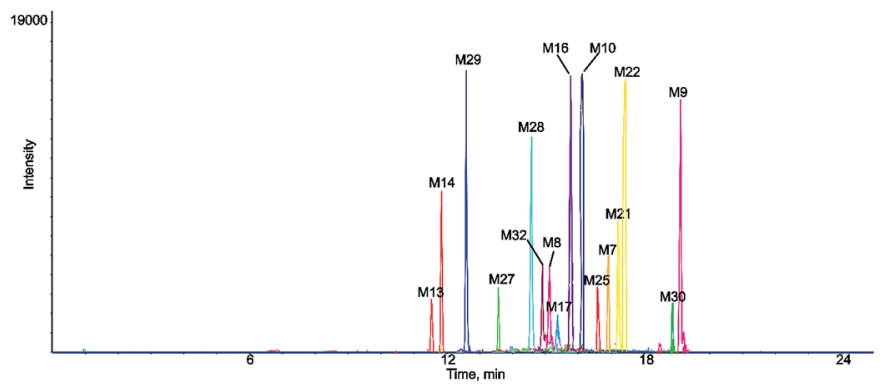

E

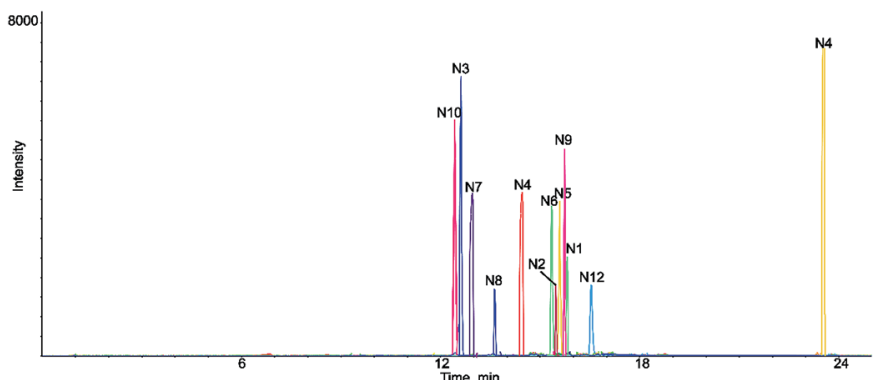

F1

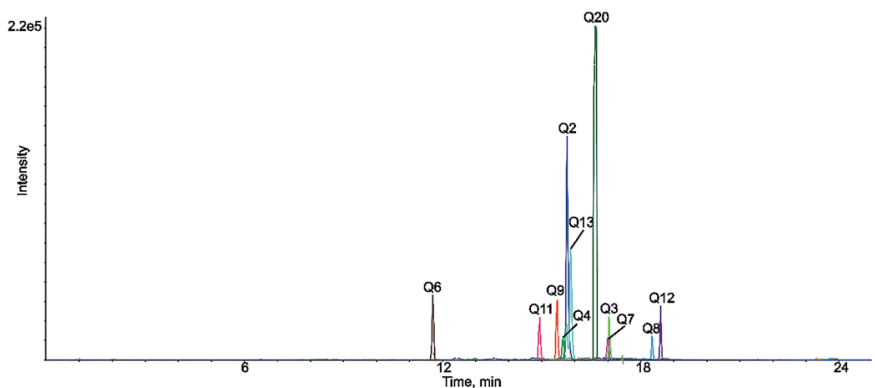

F2

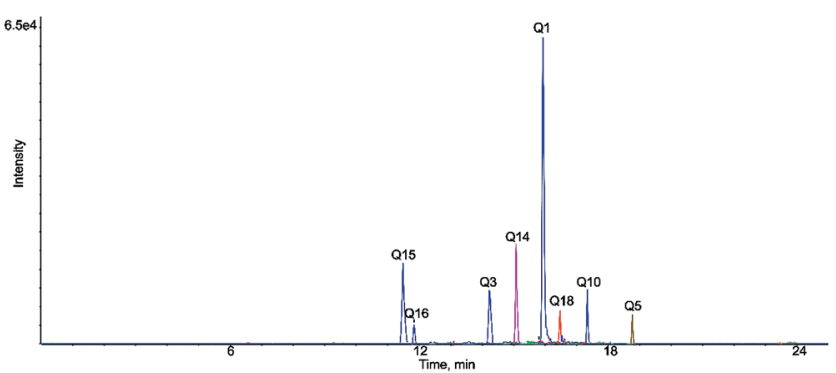

Fig. 3 Extracted ion chromatograms of all metabolites of eriocitrin in vivo and in vitro ((D1) and (D2) in vivo, (E) in rat liver microsomes, (F1) and (F2) in rat intestinal flora).
Metabolites M27 and M28 $\left(\mathrm{C}_{15} \mathrm{H}_{12} \mathrm{O}_{9} \mathrm{~S}\right)$ were detected in the negative-ion full scan mass spectra as deprotonated $[\mathrm{M}-\mathrm{H}]^{-}$ ions at $\mathrm{m} / \mathrm{z} 367.0125$, which eluted at $13.47 \mathrm{~min}$ and $14.37 \mathrm{~min}$, respectively, and were $80 \mathrm{Da}\left(\mathrm{SO}_{3}\right)$ higher than that of $\mathrm{M} 1$. According to the fragment ion at $\mathrm{m} / \mathrm{z} 349.2043$ generated by water loss and the fragment ion at $\mathrm{m} / \mathrm{z} 231.1580$ produced after the RDA reaction, sulfate conjugation took place in the A ring. Other characteristic fragment ions at $m / z 321.1743\left(\left[\mathrm{M}-\mathrm{H}_{2} \mathrm{O}-\right.\right.$ $\left.\mathrm{CO}-\mathrm{H}]^{-}\right), 287.0567\left(\left[\mathrm{M}-\mathrm{SO}_{3}-\mathrm{H}\right]^{-}\right), 269.0479\left(\left[\mathrm{M}-\mathrm{SO}_{3}-\mathrm{H}_{2} \mathrm{O}-\mathrm{H}\right]^{-}\right)$, 231.1580 (RDA reaction) and 135.0446 (RDA reaction) were also created, and the fragment ion at $m / z 151.0033$ was obtained by losing $\mathrm{SO}_{3}$ from the fragment ion at $m / z$ 231.1580. In addition, the $\operatorname{clog} P$ values of metabolites M27 and M28 were -0.235379 and 0.224621 , respectively. Hence, they were distinguished.

Metabolite M29 $\left(\mathrm{C}_{15} \mathrm{H}_{12} \mathrm{O}_{12} \mathrm{~S}_{2}\right)$ eluted at $12.68 \mathrm{~min}$ and showed the deprotonated molecular ion $[\mathrm{M}-\mathrm{H}]^{-}$at $\mathrm{m} / \mathrm{z}$ $446.9695,160 \mathrm{Da}\left(2 \mathrm{SO}_{3}\right)$ higher than that of $\mathrm{M} 1$, and generated characteristic product ions at $\mathrm{m} / \mathrm{z} 402.8724,367.0135,287.0566$, 311.2528 and 151.0041 by the loss of $\mathrm{CO}_{2}, \mathrm{SO}_{3}, 2 \mathrm{SO}_{3}$ and RDA reaction, respectively. The fragment ion at $\mathrm{m} / \mathrm{z} 311.2528$ produced by the RDA reaction generated the fragment ion at $\mathrm{m} / \mathrm{z}$ 151.0041 by loss of $2 \mathrm{SO}_{3}$.

Metabolite $\mathrm{M} 30\left(\mathrm{C}_{15} \mathrm{H}_{12} \mathrm{O}_{11} \mathrm{~S}_{2}\right)$ had an $[\mathrm{M}-\mathrm{H}]^{-}$ion of $\mathrm{m} / \mathrm{z}$ 430.9746 that eluted at $18.38 \mathrm{~min}$ and was $160 \mathrm{Da}\left(2 \mathrm{SO}_{3}\right)$ higher than that of M2. Secondary fragment ions at $\mathrm{m} / \mathrm{z} 351.0581$, 270.9703, 294.9822, and 134.9922 were generated by M30 through the loss of $\mathrm{SO}_{3}, 2 \mathrm{SO}_{3}$ and $\mathrm{RDA}$ cleavage, respectively, which implied that bis-sulfate conjugation occurred in the $\mathrm{B}$ ring.

Metabolite $\mathrm{M} 31\left(\mathrm{C}_{20} \mathrm{H}_{20} \mathrm{~N}_{2} \mathrm{O}_{7}\right)$ was detected at 13.97 min with the deprotonated molecular ion $[\mathrm{M}-\mathrm{H}]^{-}$at $\mathrm{m} / \mathrm{z}$ 399.1164, 196 Da lower than that of the parent drug. The distinctive fragment ion at $m / z 271.0683$ was observed, corresponding to the loss of glutamine. ${ }^{31-33}$ Furthermore, a strong ion at $\mathrm{m} / \mathrm{z}$ 263.0735 appeared in the secondary mass spectrum after the RDA reaction, and other characteristic fragment ions at $\mathrm{m} / \mathrm{z}$ $353.1116\left(\left[\mathrm{M}-\mathrm{CO}-\mathrm{H}_{2} \mathrm{O}-\mathrm{H}\right]^{-}\right), m / z 335.0996\left([\mathrm{M}-4 \mathrm{O}-\mathrm{H}]^{-}\right)$and $m /$ $z 291.1097\left(\left[\mathrm{M}-\mathrm{C}_{6} \mathrm{H}_{4} \mathrm{O}_{2}-\mathrm{H}\right]^{-}\right)$were observed according to the MS/MS spectrum.

Metabolite M32 $\left(\mathrm{C}_{17} \mathrm{H}_{15} \mathrm{NO}_{5}\right)$ showed the $[\mathrm{M}-\mathrm{H}]^{-}$ion at $\mathrm{m} / \mathrm{z}$ 312.0889 that eluted at $14.54 \mathrm{~min}$ and was $57 \mathrm{Da}$ higher than that of M3 and M4, indicating that it may experience the loss of $\mathrm{O}$ and $\mathrm{C}_{12} \mathrm{H}_{20} \mathrm{O}_{10}$ followed by glycine conjugation. ${ }^{31,32}$ According to the secondary fragment ion at $m / z 175.9600$ produced by RDA cleavage, the structure of M32 could be inferred. In addition, the characteristic fragment ions at $\mathrm{m} / \mathrm{z} 268.1001$ and 239.1068 were produced by $\mathrm{M} 32$ through the loss of $\mathrm{CO}_{2}$ and $\mathrm{C}_{2} \mathrm{H}_{3} \mathrm{NO}_{2}$.

\subsection{Identification of metabolites in vitro}

3.4.1. Identification of metabolites in rat liver microsomes. Metabolite $\mathrm{N} 1\left(\mathrm{C}_{21} \mathrm{H}_{22} \mathrm{O}_{10}\right)$ was detected in the negative-ion full scan mass spectrum as the deprotonated molecular ion $[\mathrm{M}-\mathrm{H}]^{-}$at $\mathrm{m} / z$ 433.1159, which eluted at $15.87 \mathrm{~min}$, was $162 \mathrm{Da}$ lower than that of eriocitrin. The typical fragment ions at $\mathrm{m} / \mathrm{z}$ 417.0309, 353.1632, 271.0645 and 135.2507 were observed 
in the MS/MS spectrum through the loss of $\mathrm{O}, 5 \mathrm{O}, \mathrm{C}_{6} \mathrm{H}_{10} \mathrm{O}_{5}$ and RDA cleavage, respectively.

Metabolite $\mathrm{N} 2\left(\mathrm{C}_{15} \mathrm{H}_{12} \mathrm{O}_{6}\right)$ eluted at $15.59 \mathrm{~min}$ and had the deprotonated molecular ion [M $-\mathrm{H}]^{-}$at $m / z$ 287.0562, a loss of $\mathrm{C}_{12} \mathrm{H}_{20} \mathrm{O}_{9}$ when compared with eriocitrin. The prominent fragment ions at $\mathrm{m} / \mathrm{z} 269.0391,241.2241,151.0039$, and 135.0451 were consistent with M1; hence, its structure was identified.

Metabolite $\mathrm{N} 3\left(\mathrm{C}_{27} \mathrm{H}_{30} \mathrm{O}_{15}\right)$ eluted at 12.59 min having a deprotonated molecular ion $[\mathrm{M}-\mathrm{H}]^{-}$at $m / z 593.1508,2 \mathrm{Da}$ $(2 \mathrm{H})$ lower than that of eriocitrin, which implied that desaturation occurred. According to the fragment ion at $\mathrm{m} / \mathrm{z} 285.0406$, $\mathrm{C}_{12} \mathrm{H}_{20} \mathrm{O}_{9}$ was lost from the parent ion, suggesting that desaturation occurred in the flavonoid skeleton. Other typical fragment ions of $\mathrm{N} 3$ at $m / z 549.1892\left(\left[\mathrm{M}-\mathrm{CO}_{2}-\mathrm{H}\right]^{-}\right), m / z 447.0645$ $\left(\left[\mathrm{M}-\mathrm{C}_{6} \mathrm{H}_{10} \mathrm{O}_{4}-\mathrm{H}\right]^{-}\right.$), and $m / z 151.0039$ (RDA reaction) were also observed, which helped to confirm the structure.

Metabolite $\mathrm{N} 4\left(\mathrm{C}_{21} \mathrm{H}_{20} \mathrm{O}_{10}\right)$ was detected at 14.49 min with the deprotonated molecular ion $[\mathrm{M}-\mathrm{H}]^{-}$at $\mathrm{m} / \mathrm{z}$ 431.0976, 164 Da lower than that of eriocitrin. Metabolite N4 generated fragment ions at $m / z 399.0170,387.0883,269.0528$ and 313.0631 by loss of $2 \mathrm{O}, \mathrm{CO}_{2}, \mathrm{C}_{6} \mathrm{H}_{10} \mathrm{O}_{5}$ and $\mathrm{RDA}$ cleavage, respectively, so $\mathrm{N} 4$ could be determined.

Metabolite $\mathrm{N} 5\left(\mathrm{C}_{21} \mathrm{H}_{24} \mathrm{O}_{10}\right)$ was detected at $15.66 \mathrm{~min}$ and displayed a deprotonated molecular ion $[\mathrm{M}-\mathrm{H}]^{-}$at $\mathrm{m} / \mathrm{z}$ 435.1320, $2 \mathrm{Da}(2 \mathrm{H})$ higher than that of $\mathrm{N} 1$. The typical fragment ions at $\mathrm{m} / \mathrm{z} \quad 389.1652\left(\left[\mathrm{M}-\mathrm{CO}-\mathrm{H}_{2} \mathrm{O}-\mathrm{H}\right]^{-}\right), 273.0560([\mathrm{M}-$ $\left.\mathrm{C}_{6} \mathrm{H}_{10} \mathrm{O}_{5}-\mathrm{H}\right]^{-}$), 298.9101 (RDA reaction) and 135.0666 (RDA reaction) were observed in its secondary mass spectrum, and the possible structure of metabolite N5 could be inferred by combining the evaluation with the fragment ion at $\mathrm{m} / \mathrm{z}$ 153.0836, which was gained from the fragment ion at $\mathrm{m} / \mathrm{z}$ 298.9101 by loss of $\mathrm{C}_{6} \mathrm{H}_{10} \mathrm{O}_{4}$.

Metabolite N6 $\left(\mathrm{C}_{23} \mathrm{H}_{24} \mathrm{O}_{12}\right)$ eluted at $15.42 \mathrm{~min}$. The MS/MS spectrum of $\mathrm{N} 6$ showed the deprotonated molecular ion [M $\mathrm{H}]^{-}$at $\mathrm{m} / \mathrm{z}$ 491.1161, which was 104 Da lower than that of eriocitrin. Based on the dominant fragment ions at $\mathrm{m} / \mathrm{z}$ $473.2817\left(\left[\mathrm{M}-\mathrm{H}_{2} \mathrm{O}-\mathrm{H}\right]^{-}\right), m / z 445.1889\left(\left[\mathrm{M}-\mathrm{H}_{2} \mathrm{O}-\mathrm{CO}-\mathrm{H}\right]^{-}\right), \mathrm{m} / \mathrm{z}$ $287.1221\left(\left[\mathrm{M}-\mathrm{C}_{6} \mathrm{H}_{4} \mathrm{O}_{3}-\mathrm{H}\right]^{-}\right)$and $\mathrm{m} / z 125.0191\left(\left[\mathrm{M}-\mathrm{C}_{17} \mathrm{H}_{18} \mathrm{O}_{9}{ }^{-}\right.\right.$ $\mathrm{H}]^{-}$), its structure was confirmed.

Metabolite $\mathrm{N} 7\left(\mathrm{C}_{21} \mathrm{H}_{20} \mathrm{O}_{12}\right)$ eluted at $12.86 \mathrm{~min}$ and displayed a deprotonated molecular ion $[\mathrm{M}-\mathrm{H}]^{-}$at $\mathrm{m} / \mathrm{z} 463.0868,30 \mathrm{Da}$ larger than that of $\mathrm{N} 1$. The characteristic fragment ions at $\mathrm{m} / \mathrm{z}$ $417.1839\left(\left[\mathrm{M}-\mathrm{CO}-\mathrm{H}_{2} \mathrm{O}-\mathrm{H}\right]^{-}\right), m / z 271.0245\left(\left[\mathrm{M}^{-} \mathrm{C}_{6} \mathrm{H}_{8} \mathrm{O}_{7}-\mathrm{H}\right]^{-}\right)$, $\mathrm{m} / \mathrm{z} 258.9180\left(\left[\mathrm{M}-\mathrm{C}_{5} \mathrm{H}_{10} \mathrm{O}_{3}-\mathrm{CO}-\mathrm{H}\right]^{-}\right)$and $\mathrm{m} / z 151.0005$ (RDA reaction) were observed in the MS/MS spectrum.

Metabolite N8 $\left(\mathrm{C}_{21} \mathrm{H}_{20} \mathrm{O}_{11}\right)$ was observed with a peak at $\mathrm{m} / \mathrm{z}$ 447.0925 in the chromatogram, which eluted at $13.67 \mathrm{~min}$ and was 14 Da higher than that of N1. According to the characteristic secondary fragment ion at $\mathrm{m} / \mathrm{z} 301.0338$ attributed to the loss of $\mathrm{C}_{6} \mathrm{H}_{10} \mathrm{O}_{4}$, the structure of $\mathrm{N} 8$ could be inferred, and other diagnostic secondary fragment ions at $m / z 429.3176\left(\left[\mathrm{M}-\mathrm{H}_{2} \mathrm{O}-\right.\right.$ $\left.\mathrm{H}]^{-}\right), m / z 285.0364\left(\left[\mathrm{M}^{-} \mathrm{C}_{6} \mathrm{H}_{10} \mathrm{O}_{4}-\mathrm{H}\right]^{-}\right)$and $m / z 151.0020$ (RDA reaction) were observed.

Metabolite N9 $\left(\mathrm{C}_{15} \mathrm{H}_{10} \mathrm{O}_{6}\right)$, with an $[\mathrm{M}-\mathrm{H}]^{-}$ion of $\mathrm{m} / \mathrm{z}$ 285.0406, eluted at $15.85 \mathrm{~min}$ and exhibited a mass $310 \mathrm{Da}$ lower than that of the parent drug. The typical fragment ions of N9 at $m / z 267.1811\left(\left[\mathrm{M}-\mathrm{H}_{2} \mathrm{O}-\mathrm{H}\right]^{-}\right), m / z 239.0672\left(\left[\mathrm{M}-\mathrm{H}_{2} \mathrm{O}-\mathrm{CO}-\right.\right.$
$\left.\mathrm{H}]^{-}\right), m / z 223.0274\left(\left[\mathrm{M}-\mathrm{H}_{2} \mathrm{O}-\mathrm{CO}-\mathrm{O}-\mathrm{H}\right]^{-}\right)$and $m / z 257.0448([\mathrm{M}-$ $\mathrm{CO}-\mathrm{H}]^{-}$) were detected in the MS/MS spectrum, and the fragment ion at $\mathrm{m} / \mathrm{z} 119.0614$ was formed by the loss of $\mathrm{O}$ after RDA cleavage.

Metabolite $\mathrm{N} 10 \quad\left(\mathrm{C}_{27} \mathrm{H}_{32} \mathrm{O}_{6}\right)$ displayed the deprotonated molecular ion $[\mathrm{M}-\mathrm{H}]^{-}$at $\mathrm{m} / \mathrm{z} 611.1615$ with a retention time of $12.39 \mathrm{~min}$ and a mass $16 \mathrm{Da}(\mathrm{O})$ higher than that of eriocitrin. $\mathrm{N} 10$ created characteristic product ions at $\mathrm{m} / \mathrm{z} 303.0505$ ([M$\left.\left.\mathrm{C}_{12} \mathrm{H}_{20} \mathrm{O}_{9}-\mathrm{H}\right]^{-}\right), \quad m / z \quad 287.0565 \quad\left(\left[\mathrm{M}^{-} \mathrm{C}_{12} \mathrm{H}_{20} \mathrm{O}_{10}-\mathrm{H}\right]^{-}\right), \quad m / z$ $227.9309\left(\left[\mathrm{M}-\mathrm{C}_{12} \mathrm{H}_{20} \mathrm{O}_{9}-3 \mathrm{O}-\mathrm{CO}-\mathrm{H}\right]^{-}\right), m / z 151.0036$ (RDA reaction) and $\mathrm{m} / z 135.0468$ (RDA reaction), indicating that the oxidation reaction occurred in the $\mathrm{B}$ ring.

Metabolite $\mathrm{N} 11\left(\mathrm{C}_{22} \mathrm{H}_{24} \mathrm{O}_{10}\right)$ eluted at $23.89 \mathrm{~min}$ and had the deprotonated molecular ion at $\mathrm{m} / \mathrm{z} 447.1328[\mathrm{M}-\mathrm{H}]^{-}$, which was $14 \mathrm{Da}\left(\mathrm{CH}_{2}\right)$ higher than that of N1. Characteristic product ions at $m / z 417.1216,148.9971$ and 135.0752 were in line with M20. Additionally, the distinctive fragment ion at 285.1388 ([M$\left.\mathrm{C}_{6} \mathrm{H}_{10} \mathrm{O}_{5}-\mathrm{H}\right]^{-}$) was yielded, so the possible structures of N11 could be determined.

Metabolite $\mathrm{N} 12\left(\mathrm{C}_{16} \mathrm{H}_{14} \mathrm{O}_{7}\right)$ had a deprotonated molecular ion $[\mathrm{M}-\mathrm{H}]^{-}$at $m / z 317.0694$, a retention time of $16.61 \mathrm{~min}$ and a mass that was $30 \mathrm{Da}\left(\mathrm{CH}_{2} \mathrm{O}\right)$ higher than that of $\mathrm{N} 2$. The dominant product ions at $\mathrm{m} / \mathrm{z} 299.0555,180.9719$ and 165.0828 were consistent with those seen for M26; thus, its possible structures could be inferred.

3.4.2. Identification of metabolites in rat intestinal flora. Metabolite Q1 $\left(\mathrm{C}_{21} \mathrm{H}_{22} \mathrm{O}_{10}\right)$ eluted at $15.96 \mathrm{~min}$, possessing the deprotonated molecular ion $[\mathrm{M}-\mathrm{H}]^{-}$at $\mathrm{m} / z$ 433.1166, which was $162 \mathrm{Da}\left(\mathrm{C}_{6} \mathrm{H}_{10} \mathrm{O}_{5}\right)$ lower than that of eriocitrin. The typical fragment ions at $\mathrm{m} / \mathrm{z}$ 417.2409, 387.2026, 271.0645 and 151.3214 were created through the loss of $\mathrm{O}, \mathrm{CO}$ and $\mathrm{H}_{2} \mathrm{O}, \mathrm{C}_{6} \mathrm{H}_{10} \mathrm{O}_{5}$ and RDA cleavage, respectively.

Metabolite Q2 $\left(\mathrm{C}_{15} \mathrm{H}_{12} \mathrm{O}_{6}\right)$ was observed with a precursor ion at $\mathrm{m} / \mathrm{z} 287.0561$ which eluted at $15.74 \mathrm{~min}$ and was $308 \mathrm{Da}$ $\left(\mathrm{C}_{12} \mathrm{H}_{20} \mathrm{O}_{9}\right)$ lower than that of eriocitrin. It was recognized through the conspicuous fragment ions at $\mathrm{m} / \mathrm{z}$ 269.0485, 241.2146, 151.0038 and 135.0451 that were consistent with M1 and $\mathrm{N} 2$.

Metabolite Q3 $\left(\mathrm{C}_{15} \mathrm{H}_{12} \mathrm{O}_{5}\right)$ eluted at $17.02 \mathrm{~min}$ and had the deprotonated molecular ion $[\mathrm{M}-\mathrm{H}]^{-}$at $m / z 271.0611,324 \mathrm{Da}$ $\left(\mathrm{C}_{12} \mathrm{H}_{20} \mathrm{O}_{10}\right)$ lower than that of $\mathrm{Q} 0$. The distinctive fragment ions at $m / z 253.1802,243.0655,227.0713$ and 135.0105 yielded by Q3 were in accordance with $\mathrm{M} 2$, so it was verified.

Metabolites Q4 and Q5 $\left(\mathrm{C}_{15} \mathrm{H}_{12} \mathrm{O}_{4}\right)$ were isomeric metabolites with the deprotonated $[\mathrm{M}-\mathrm{H}]^{-}$ions at $\mathrm{m} / \mathrm{z} 255.0675$ and 255.0659, respectively, masses that were $16 \mathrm{Da}(\mathrm{O})$ lower than that of Q3. Q4 and Q5 eluted at $15.52 \mathrm{~min}$ and $18.49 \mathrm{~min}$, respectively. The crucial fragment ions of Q4 at $\mathrm{m} / z 237.2196$ and 109.0724 were similar to those of M3, which confirmed that the reaction occurred in ring A. In addition, Q4 and Q5 were also verified based on their $\operatorname{cog} P$ values of 2.2109 and 2.99394, respectively.

Metabolite Q6 $\left(\mathrm{C}_{14} \mathrm{H}_{12} \mathrm{O}_{5}\right)$ exhibited the $[\mathrm{M}-\mathrm{H}]^{-}$ion of $\mathrm{m} / \mathrm{z}$ 259.0608, which eluted at $11.79 \mathrm{~min}$ and was $28 \mathrm{Da}$ (CO) lower than that of Q2. The dominant product ions at $\mathrm{m} / \mathrm{z} 241.0505$, 213.0568, 195.1018, 183.0887 and 135.0011 were consistent with M5; thus, the structure of Q6 could be inferred. 
Metabolite Q7 $\left(\mathrm{C}_{15} \mathrm{H}_{10} \mathrm{O}_{5}\right)$ eluted at $16.98 \mathrm{~min}$ and displayed a deprotonated molecular ion $[\mathrm{M}-\mathrm{H}]^{-}$at $\mathrm{m} / \mathrm{z} 269.0456,18 \mathrm{Da}$ $\left(\mathrm{H}_{2} \mathrm{O}\right)$ lower than that of Q2. Q7 generated fragment ions at $\mathrm{m} / \mathrm{z}$ 241.0545, 225.0605, 197.0598, 181.0638 and 151.0020 by successively losing $\mathrm{CO}, \mathrm{O}, \mathrm{CO}$, and $\mathrm{O}$ and undergoing RDA cleavage.

Metabolite Q8 $\left(\mathrm{C}_{15} \mathrm{H}_{10} \mathrm{O}_{4}\right)$ eluted at $18.33 \mathrm{~min}$ and exhibited the deprotonated molecular ion $[\mathrm{M}-\mathrm{H}]^{-}$at $\mathrm{m} / \mathrm{z} 253.0505$, which was $18 \mathrm{Da}\left(\mathrm{H}_{2} \mathrm{O}\right)$ lower than that of Q3. It was confirmed by the characteristic fragment ions at $m / z 225.0217,209.0610$, 181.0660 and 119.0488, which were in line with M6.

Metabolite Q9 $\left(\mathrm{C}_{21} \mathrm{H}_{24} \mathrm{O}_{10}\right)$ exhibited the deprotonated molecular ion $[\mathrm{M}-\mathrm{H}]^{-}$of $\mathrm{m} / \mathrm{z}$ 435.1323, was observed at 15.32 min and was $2 \mathrm{Da}(2 \mathrm{H})$ higher than that of Q1. The possible structure of Q9 could be inferred by the characteristic fragment ions at $m / z 391.6900\left(\left[\mathrm{M}-\mathrm{CO}_{2}-\mathrm{H}\right]^{-}\right), m / z 389.2463([\mathrm{M}-$ $\left.\left.\mathrm{CO}-\mathrm{H}_{2} \mathrm{O}-\mathrm{H}\right]^{-}\right), \quad m / z \quad 273.0863\left(\left[\mathrm{M}-\mathrm{C}_{6} \mathrm{H}_{10} \mathrm{O}_{5}-\mathrm{H}\right]^{-}\right)$and $m / z$ 135.0793 (RDA reaction).
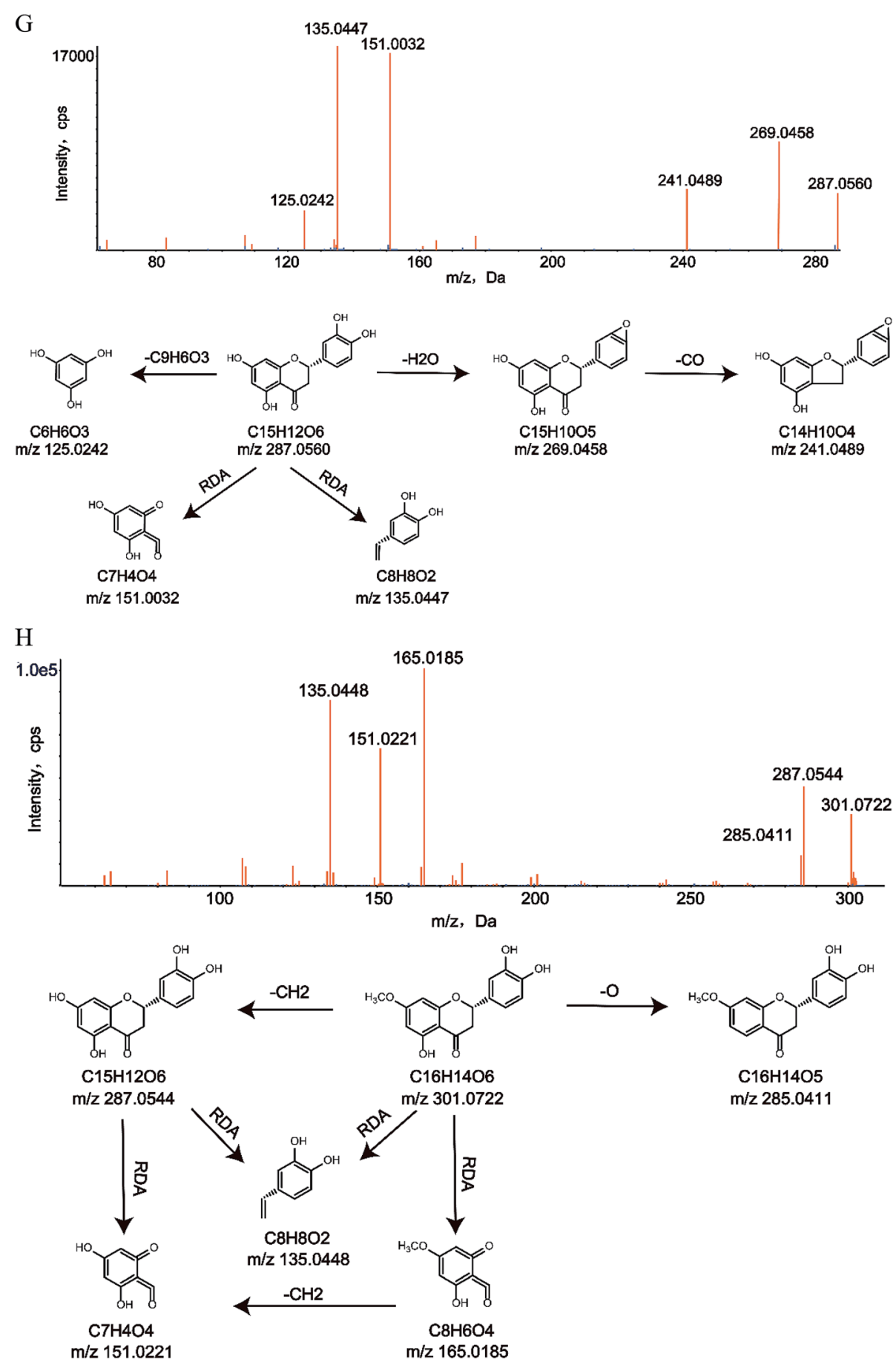

Fig. 4 MS/MS spectra and major proposed fragmentation patterns of $M 1(G), M 22(H)$ and $M 28(I)$. 
I
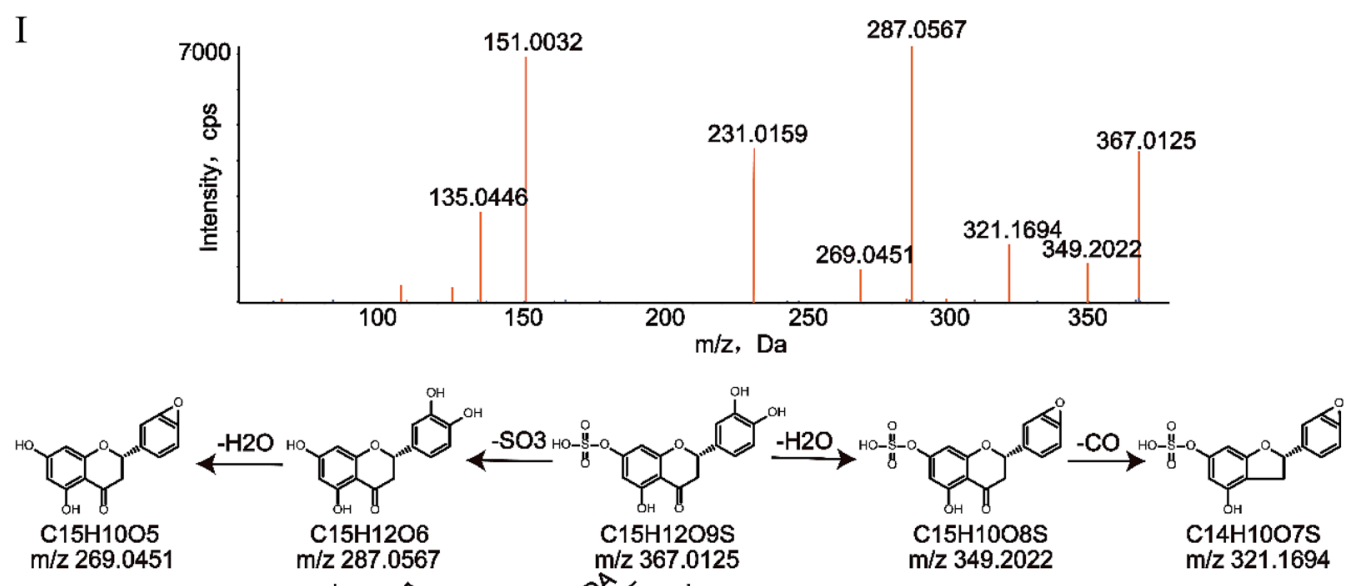

$\mathrm{m} / \mathrm{z} 269.0451$

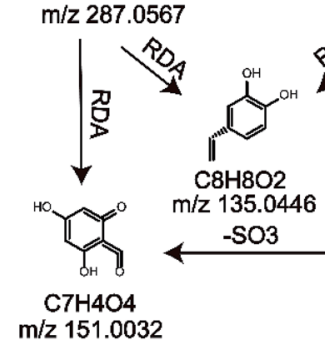

$\mathrm{m} / \mathrm{z} 367.0125$

$\mathrm{m} / \mathrm{z} 349.2022$

C14H10O7S
$\mathrm{m} / \mathrm{z} 321.1694$

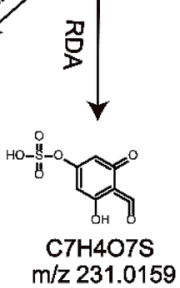

Fig. 4 (contd.)

Metabolite Q10 $\left(\mathrm{C}_{15} \mathrm{H}_{14} \mathrm{O}_{5}\right)$ was detected at 16.33 min with the deprotonated molecular ion $[\mathrm{M}-\mathrm{H}]^{-}$at $m / z 273.0766,2 \mathrm{Da}$ $(2 \mathrm{H})$ higher than $\mathrm{Q} 3$, which created fragment ions at $\mathrm{m} / \mathrm{z}$ $245.0473,227.1979,209.1302,165.0140$ and 135.0435 by dropping $\mathrm{CO}, \mathrm{CH}_{2} \mathrm{O}_{2}$ and $\mathrm{O}, 4 \mathrm{O}, \mathrm{C}_{6} \mathrm{H}_{4} \mathrm{O}_{2}$ and undergoing RDA cleavage, respectively.

Metabolites Q11 and Q12 $\left(\mathrm{C}_{15} \mathrm{H}_{14} \mathrm{O}_{4}\right)$ arose as deprotonated molecules $[\mathrm{M}-\mathrm{H}]^{-}$at $m / z 257.0818$ and 257.0820 , with retention times of $14.90 \mathrm{~min}$ and $18.61 \mathrm{~min}$, respectively. Their masses were $2 \mathrm{Da}(2 \mathrm{H})$ higher than those of Q4 and Q5. According to the product ions seen at $m / z 241.0505$ ([M-O-H] $]^{-}$), $239.0718\left(\left[\mathrm{M}-\mathrm{H}_{2} \mathrm{O}-\mathrm{H}\right]^{-}\right), 213.0933\left(\left[\mathrm{M}-\mathrm{CO}_{2}-\mathrm{H}\right]^{-}\right), \quad 137.0228$ (RDA reaction), 135.0793 (RDA reaction), 121.0304 (RDA reaction) and 119.0492 (RDA reaction) in the secondary mass spectra, the structures of metabolites Q11 and Q12 could be predicted. Additionally, Q11 and Q12 were also verified based on their $\operatorname{cog} P$ values of 1.462 and 1.5722 , respectively.

Metabolite Q13 $\left(\mathrm{C}_{15} \mathrm{H}_{10} \mathrm{O}_{6}\right)$ eluted at $15.86 \mathrm{~min}$ and showed the deprotonated molecular ion $[\mathrm{M}-\mathrm{H}]^{-}$at $\mathrm{m} / z$ 285.0403, which was $14 \mathrm{Da}$ higher than that of Q3. It contained the product ions at $m / z$ 267.0287, 257.0427, 223.0309 and 149.0227, which were consistent with M10. In addition, the product ion at $\mathrm{m} / z 133.0291$ was attributed to loss of $\mathrm{O}$ after the RDA cleavage.

Metabolite Q14 $\left(\mathrm{C}_{17} \mathrm{H}_{14} \mathrm{O}_{5}\right)$ was obtained with a precursor ion at $\mathrm{m} / \mathrm{z} 297.0762$, which eluted at $14.81 \mathrm{~min}$ and was $42 \mathrm{Da}$ larger than that of Q5, indicating that it may undergo the loss of $\mathrm{O}$ and $\mathrm{C}_{12} \mathrm{H}_{20} \mathrm{O}_{10}$ followed by acetylation. Q14 generated fragment ions at $\mathrm{m} / \mathrm{z} 281.0060,264.9847$ and 253.0871 through loss of $\mathrm{O}, 2 \mathrm{O}$ and $\mathrm{CO}_{2}$, respectively. It could be determined from the key fragment ions at $\mathrm{m} / \mathrm{z} 160.9785$ and 135.0547 produced by the RDA reaction that both oxygen loss and acetylation occurred in the B ring.
Metabolites Q15 and Q16 $\left(\mathrm{C}_{19} \mathrm{H}_{16} \mathrm{O}_{6}\right)$ were observed in the mass spectrum at $\mathrm{m} / \mathrm{z} 339.0872$, with retention times of $11.52 \mathrm{~min}$ and $11.70 \mathrm{~min}$, respectively. The masses which were 84 Da higher than those of Q4 and Q5. Secondary fragment ions at $m / z 311.0629,297.1756$ and 254.9424 were generated through the loss of $\mathrm{CO}, \mathrm{C}_{2} \mathrm{H}_{2} \mathrm{O}$ and $2 \mathrm{C}_{2} \mathrm{H}_{2} \mathrm{O}$, respectively. Moreover, the fragment ions at $\mathrm{m} / \mathrm{z} 219.0413,119.0621$ and $177.8865,161.0382$ produced after RDA reactions of Q15 and Q16, respectively, were similar to M13 and M14, so the structures of metabolites Q15 and Q16 could be inferred. In addition, the clog $P$ values of Q15 and Q16 were 1.9929 and 2.28159, respectively, which also supports the confirmation of the structures.

Metabolite Q17 $\left(\mathrm{C}_{15} \mathrm{H}_{12} \mathrm{O}_{7}\right)$ eluted at $15.49 \mathrm{~min}$, which presented a deprotonated molecular ion $[\mathrm{M}-\mathrm{H}]^{-}$at $m / z$ 303.0521, $16 \mathrm{Da}(\mathrm{O})$ higher than that of Q2. The secondary fragment ions formed at $\mathrm{m} / \mathrm{z} 285.1301,257.2180,151.0760$ and 135.0594 through the loss of $\mathrm{H}_{2} \mathrm{O}, \mathrm{CO}$ and $\mathrm{H}_{2} \mathrm{O}$ and undergoing RDA cleavage, respectively, were consistent with M15, so the structure of Q17 could be ascertained.

Metabolite Q18 $\left(\mathrm{C}_{16} \mathrm{H}_{14} \mathrm{O}_{5}\right)$ was detected at $14.09 \mathrm{~min}$ and displayed the deprotonated molecular ion $[\mathrm{M}-\mathrm{H}]^{-}$at $\mathrm{m} / \mathrm{z}$ 285.0764, $14 \mathrm{Da}\left(\mathrm{CH}_{2}\right)$ higher than that of Q3. Based on the fragment ions at $m / z 149.0227$ and 135.0007 that were produced by the RDA reaction, methylation occurred in ring A. Other key fragment ions at $m / z 269.0475\left([\mathrm{M}-\mathrm{O}-\mathrm{H}]^{-}\right), m / z 267.2314([\mathrm{M}-$ $\left.\left.\mathrm{H}_{2} \mathrm{O}-\mathrm{H}\right]^{-}\right)$and $m / z 239.0588\left(\left[\mathrm{M}-\mathrm{H}_{2} \mathrm{O}-\mathrm{CO}-\mathrm{H}\right]^{-}\right)$were also observed to help confirm the structure of Q18.

Metabolite Q19 $\left(\mathrm{C}_{16} \mathrm{H}_{14} \mathrm{O}_{4}\right)$ eluted at 16.31 min with the deprotonated molecular ion [M- H] $]^{-}$at $m / z$ 269.0822, which was $14 \mathrm{Da}\left(\mathrm{CH}_{2}\right)$ higher than that of Q4. The key fragment ions at $\mathrm{m} / \mathrm{z}$ 132.9781 and 135.0695 produced by RDA reaction were in accordance with M25, so the structure of Q19 could be confirmed. 
Metabolite Q20 $\left(\mathrm{C}_{16} \mathrm{H}_{14} \mathrm{O}_{7}\right)$ displayed a peak at $16.70 \mathrm{~min}$ as well as a deprotonated molecular ion $[\mathrm{M}-\mathrm{H}]^{-}$at $\mathrm{m} / \mathrm{z} 317.0671$, $30 \mathrm{Da}\left(\mathrm{CH}_{2} \mathrm{O}\right)$ higher than that of Q2. It was noted that the characteristic ions at $\mathrm{m} / \mathrm{z} 302.0746,299.0547,271.0600$, 180.9713, 165.0804, 151.0016 and 135.0452 were similar to those of M26, so the possible structures of Q20 could be inferred.

In this study, a total of 41 metabolites were identified: 32 metabolites were detected in vivo, including 6 metabolites in plasma, 14 metabolites in bile, 19 metabolites in urine and 13 metabolites in faeces. Meanwhile, 27 metabolites were observed in vitro, including 12 metabolites in liver microsomes and 20 metabolites in intestinal flora. Representative MS/MS spectra are shown in Fig. 4, and the proposed metabolic pathways of eriocitrin in vivo, in rat liver microsomes and in rat intestinal flora are shown in Fig. 5. It is worth mentioning that the loss of $\mathrm{C}_{6} \mathrm{H}_{10} \mathrm{O}_{5}, \mathrm{C}_{12} \mathrm{H}_{20} \mathrm{O}_{9}$, and $\mathrm{C}_{12} \mathrm{H}_{20} \mathrm{O}_{10}$ was the primary metabolic step that produced further reactions such as the loss of $\mathrm{CO}$, the loss of water, hydrogenation, $\mathrm{N}$-acetylation, ketone formation, oxidation and methylation. Nevertheless, no sulfate conjugation, glutamine conjugation and glycine conjugation occurred in vitro, and desaturation and demethylation to carboxylic acid metabolites were not discovered in vivo but were found in rat liver microsomes.

Although glutamine conjugation and glycine conjugation did not seem to be very common in metabolism, they can occur. $^{31-33}$ In this study, due to the loss of a powerful sugar group at C-7 in M31 and the 3'-hydroxyl in M32, the steric hindrance would decrease, and glutamine conjugation and glycine conjugation could occur at the 5 and $4^{\prime}$ sites, respectively.

Protein precipitation with methanol and liquid-liquid extraction with ethyl acetate were used in this research to

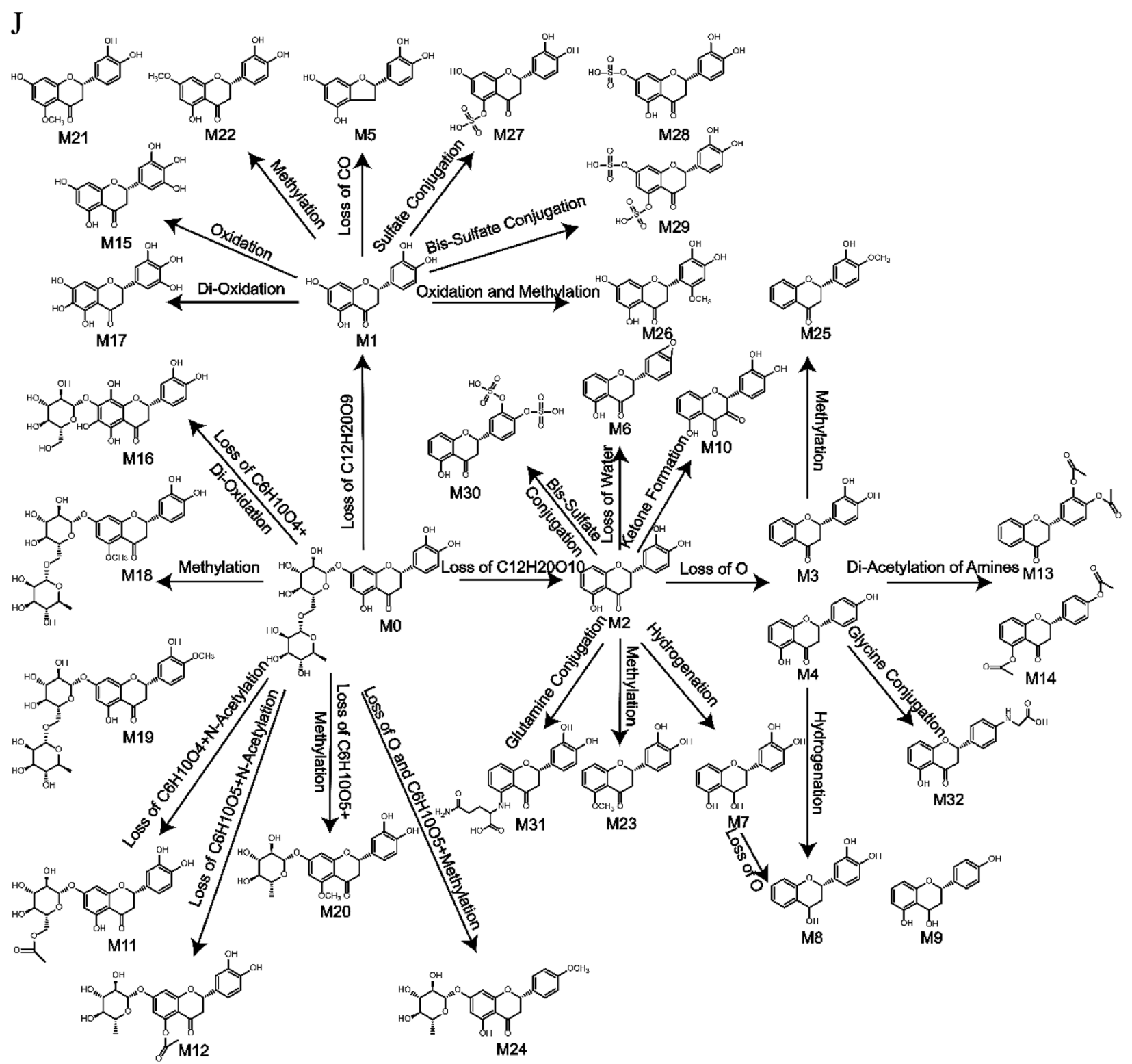

Fig. 5 Metabolic profile and proposed metabolic pathways of eriocitrin in vivo and in vitro ((J) in vivo, (K) in rat liver microsomes, (L) in rat intestinal flora). 
K

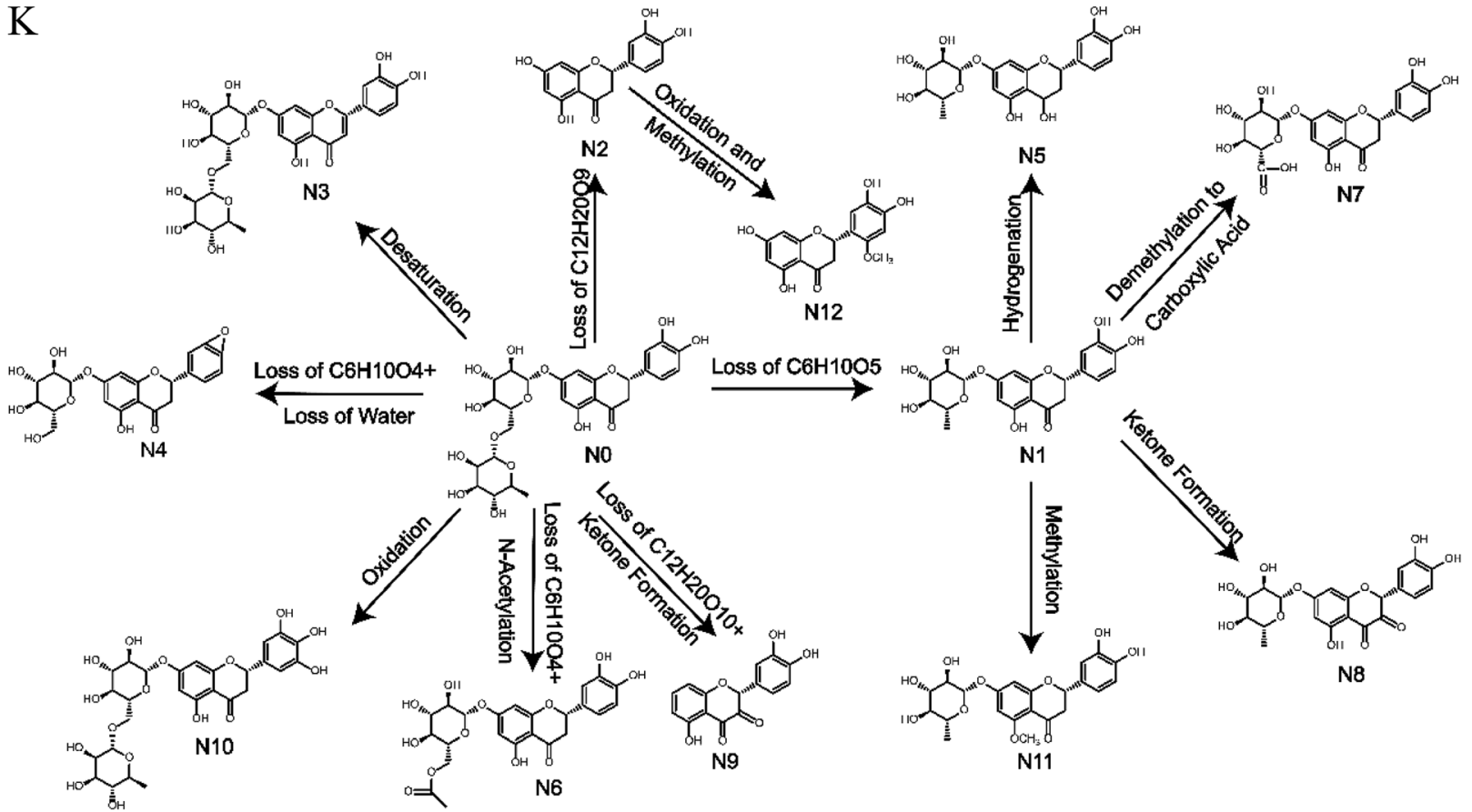

L

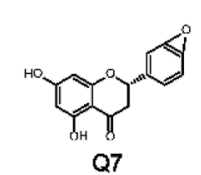
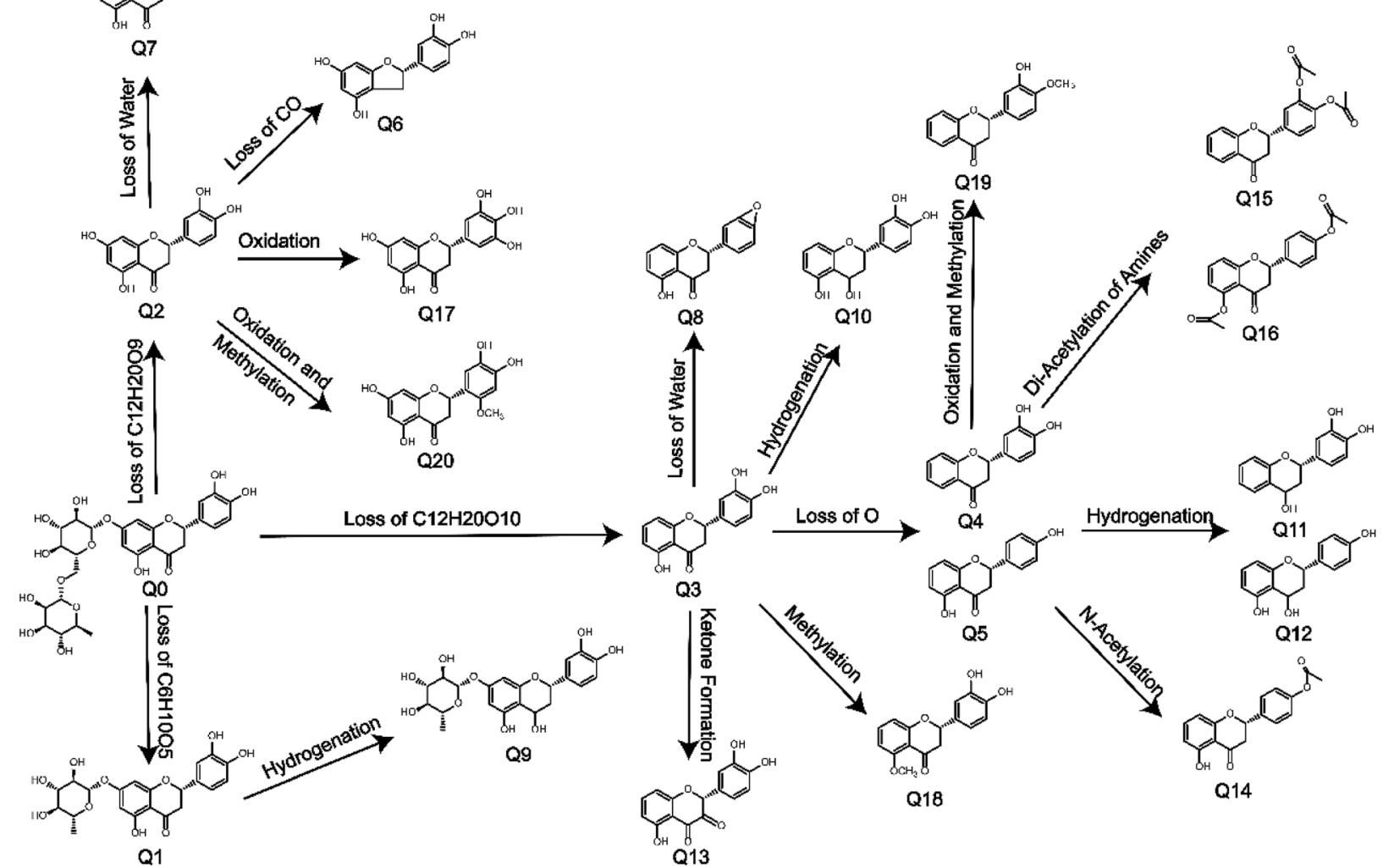

Fig. 5 (contd.)

acquire more types and quantities of metabolites. The results showed that 13 metabolites were extracted by methanol and ethyl acetate simultaneously, additionally, 14 metabolites can only be extracted from methanol and 5 metabolites can just be extracted from ethyl acetate, which did increase the types and the number of metabolites of eriocitrin. Meanwhile, we can see that more metabolites were extracted from methanol than from 
ethyl acetate, which may be related to their ability to form hydrogen bonds and polarity. ${ }^{34}$

It has been reported in the literature that eriocitrin has strong antioxidant activity. ${ }^{4}$ In this paper, oxidation occurred both in vivo and in vitro and was found to be a vital metabolic reaction of eriocitrin, which may be related to its strong antioxidant activity. In addition, many of the metabolites of eriocitrin have been studied. For example, M1 (N2, Q2), namely, eriodictyol, a natural flavonoid compound present in citrus fruits, has been reported to have broad bioactivities such as antioxidant, anti-inflammatory, immunomodulatory and antidiabetic activities. ${ }^{35-37}$ It is worth mentioning that eriodictyol was found to be one of the most potent insulin secretagogues among hundreds of compounds tested. ${ }^{38}$ M19b, namely, hesperidin, a type of citrus bioflavonoid distributed in foods including grapefruits, oranges and lemons, has many pharmacological activities, such as antioxidant, anti-depression and antitumour activities. ${ }^{39-41}$ Overall, the identification of metabolites of eriocitrin provides a basis for new pharmacological studies, and these metabolites will be further explored in the future.

\section{Conclusions}

In conclusion, an efficient strategy for screening and identifying the metabolites of eriocitrin in vivo and in vitro was established first by UHPLC-Q-TOF-MS/MS using online data acquisition and multiple data processing techniques. The results showed that a total of 41 metabolites were identified: 32 metabolites were detected in vivo (6 metabolites in the plasma, 14 metabolites in the bile, 19 metabolites in the urine and 13 metabolites in the faeces), and 27 metabolites were detected in vitro (12 metabolites in the rat liver microsomes and 20 metabolites in rat intestinal flora) under the experimental conditions. In addition to identifying the above metabolites, we also elucidated the metabolic pathways of eriocitrin. Moreover, the incubation of liver microsomes and intestinal flora was applied to eriocitrin for the first time. It was also the first study to investigate the metabolic mechanisms of eriocitrin in vivo and in vitro, all of which provided reference and valuable evidence for further development of new pharmaceuticals and pharmacological mechanisms, laying a foundation for clinical examination and application.

\section{Conflicts of interest}

All the authors have declared no conflict of interest.

\section{Acknowledgements}

The project was financially supported by the National Natural Science Foundation of China (No. 81473180). Thanks to the Department of Pharmaceutical Analysis, School of Pharmacy, Hebei Medical University for the instrument support.

\section{References}

1 M. Makni, R. Jemai, W. Kriaa, Y. Chtourou and H. Fetoui, BioMed Res. Int., 2018, 2018, 6251546.

2 X. Dong, Y. Hu, Y. Li and Z. Zhou, Sci. Hortic., 2019, 243, 281289.

3 J. J. Peterson, G. R. Beecher, S. A. Bhagwat, J. T. Dwyer, S. E. Gebhardt, D. B. Haytowitz and J. M. Holden, J. Food Compos. Anal., 2006, 19, S74-S80.

4 M. Hajimahmoodi, G. Moghaddam, S. M. Mousavi, N. Sadeghi, M. R. Oveisi and B. Jannat, Trop. J. Pharm. Res., 2014, 13, 951-956.

5 P. S. Ferreira, L. C. Spolidorio, J. A. Manthey and T. B. Cesar, Food Funct., 2016, 7, 2675-2681.

6 K.-i. Minato, Y. Miyake, S. Fukumoto, K. Yamamoto, Y. Kato, Y. Shimomura and T. Osawa, Life Sci., 2003, 72, 1609-1616.

7 M. Hiramitsu, Y. Shimada, J. Kuroyanagi, T. Inoue, T. Katagiri, L. Zang, Y. Nishimura, N. Nishimura and T. Tanaka, Sci. Rep., 2014, 4, 3708.

8 Y. Miyake, E. Suzuki, S. Ohya, S. Fukumoto, M. Hiramitsu, K. Sakaida, T. Osawa and Y. Furuichi, J. Food Sci., 2006, 71, S633-S637.

9 Z. Wang, H. Zhang, J. Zhou, X. Zhang, L. Chen, K. Chen and Z. Huang, Cancer Chemother. Pharmacol., 2016, 78, 11431150.

10 Y. Miyake, K. Shimoi, S. Kumazawa, K. Yamamoto, N. Kinae and T. Osawa, J. Agric. Food Chem., 2000, 48, 3217-3224.

11 M. W. Attwa, A. A. Kadi, H. W. Darwish and H. Alrabiah, Clin. Chim. Acta, 2018, 482, 84-94.

12 A. A. Kadi, S. M. Amer, H. W. Darwish and M. W. Attwa, $R S C$ Adv., 2017, 7, 36279-36287.

13 M. W. Attwa, A. A. Kadi, H. Alrabiah and H. W. Darwish, J. Pharm. Biomed. Anal., 2018, 160, 19-30.

14 O. A. Almazroo, M. K. Miah and R. Venkataramanan, Clin. Liver Dis., 2017, 21, 1-20.

15 H. Li, J. He and W. Jia, Expert Opin. Drug Metab. Toxicol., 2016, 12, 31-40.

16 K. Noh, Y. R. Kang, M. R. Nepal, R. Shakya, M. J. Kang, W. Kang, S. Lee, H. G. Jeong and T. C. Jeong, Arch. Pharm. Sci. Res., 2017, 40, 1345-1355.

17 J. Y. Zhang, Z. J. Wang, Y. Li, Y. Liu, W. Cai, C. Li, J. Q. Lu and Y. J. Qiao, Talanta, 2016, 147, 16-27.

18 Z. Yisimayili, X. Guo, H. Liu, Z. Xu, R. Abdulla, H. Akber Aisa and C. Huang, J. Pharm. Biomed. Anal., 2019, 165, 251-260.

19 M. Liao, X. Diao, X. Cheng, Y. Sun and L. Zhang, RSC Adv., 2018, 8, 14925-14935.

20 C. Liang, X. Zhang, X. Diao, M. Liao, Y. Sun and L. Zhang, J. Chromatogr. B: Anal. Technol. Biomed. Life Sci., 2018, 1084, 69-79.

21 X. Diao, M. Liao, X. Cheng, C. Liang, Y. Sun, X. Zhang and L. Zhang, Biomed. Chromatogr., 2018, e4263.

22 T. Tian, Y. Jin, Y. Ma, W. Xie, H. Xu, K. Zhang, L. Zhang and Y. Du, J. Chromatogr. B: Anal. Technol. Biomed. Life Sci., 2015, 1006, 80-92.

23 L. Hou, Y. Jin, W. Sun, S. Guan, H. Xu, Q. Wang, L. Zhang and Y. Du, Fitoterapia, 2019, 133, 85-95. 
24 X. Zhang, C. Liang, J. Yin, Y. Sun and L. Zhang, RSC Adv., 2018, 8, 11813-11827.

25 P. Jia, Y. Zhang, Q. Zhang, Y. Sun, H. Yang, H. Shi, X. Zhang and L. Zhang, Biomed. Chromatogr., 2016, 30, 1498-1505.

26 L. Yuan, C. Liang, X. Diao, X. Cheng, M. Liao and L. Zhang, Xenobiotica, 2018, 48, 332-341.

27 W. Xie, Y. Jin, L. Hou, Y. Ma, H. Xu, K. Zhang, L. Zhang and Y. Du, J. Pharm. Biomed. Anal., 2017, 145, 865-878.

28 Y. Ma, W. Xie, T. Tian, Y. Jin, H. Xu, K. Zhang and Y. Du, Anal. Biochem., 2016, 511, 61-73.

29 X. Zhang, J. Yin, C. Liang, Y. Sun and L. Zhang, J. Agric. Food Chem., 2017, 65, 10959-10972.

30 D. Yao, Y. Wang, C. Huo, Y. Wu, M. Zhang, L. Li, Q. Shi, H. Kiyota and X. Shi, Food Chem., 2017, 214, 328-338.

31 Y. Chen, X. Feng, L. Li, X. Zhang, K. Song, X. Diao, Y. Sun and L. Zhang, J. Pharm. Biomed. Anal., 2019, 169, 19-29.

32 X. Zhang, J. Yin, C. Liang, Y. Sun and L. Zhang, J. Chromatogr. B: Anal. Technol. Biomed. Life Sci., 2017, 10611062, 193-208.

33 M. Liao, X. Cheng, X. Diao, Y. Sun and L. Zhang, J. Chromatogr. B: Anal. Technol. Biomed. Life Sci., 2017, 10681069, 297-312.
34 N. Zhang, Z. Shen, C. Chen, G. He and C. Hao, J. Mol. Liq., 2015, 203, 90-97.

35 Y. Wang, Y. Chen, Y. Chen, B. Zhou, X. Shan and G. Yang, Biomed. Pharmacother., 2018, 107, 1128-1134.

36 P. Lv, J. Yu, X. Xu, T. Lu and F. Xu, J. Cell. Biochem., 2019, 120, 5644-5651.

37 I. Mokdad-Bzeouich, N. Mustapha, A. Sassi, A. Bedoui, M. Ghoul, K. Ghedira and L. Chekir-Ghedira, Cell Stress Chaperones, 2016, 21, 773-781.

38 A. Hameed, R. M. Hafizur, N. Hussain, S. A. Raza, M. Rehman, S. Ashraf, Z. Ul-Haq, F. Khan, G. Abbas and M. I. Choudhary, Eur. J. Pharmacol., 2018, 820, 245-255.

39 S. Estruel-Amades, M. Massot-Cladera, P. Garcia-Cerda, F. J. Perez-Cano, A. Franch, M. Castell and M. CampsBossacoma, Nutrients, 2019, 11, 783.

40 H. Fu, L. Liu, Y. Tong, Y. Li, X. Zhang, X. Gao, J. Yong, J. Zhao, D. Xiao, K. Wen and H. Wang, Eur. J. Pharmacol., 2019, 853, 236-246.

41 J. M. P. Ferreira de Oliveira, C. Santos and E. Fernandes, Phytomedicine, 2019, 152887. 